\title{
Detrital zircon provenance of Carboniferous sandstones of the Variscan Externides (SW Poland) - record of the eastern Variscides exhumation
}

\author{
Urszula Zagórska ${ }^{1}$ (1) $\cdot$ Sylwia Kowalska ${ }^{1} \cdot$ Jiří Sláma $^{2} \cdot$ Beata Dziubińska $^{3} \cdot \mathrm{Krzysztof} \mathrm{Wolański}^{4}$
}

Received: 3 September 2019 / Accepted: 9 June 2020 / Published online: 17 July 2020

(c) The Author(s) 2020

\begin{abstract}
The Variscan Externides in the area of south-western Poland (the basement of the Fore-Sudetic Monocline), are considered an extension of the Rheno-Hercynian Zone of the Variscan Orogen. The Externides are made of Carboniferous siliciclastic sediments, the exact stratigraphic age and provenance of which are not known in detail. To constrain the sedimentary evolution and detritus provenance of the Variscan external belt, eight sandstone samples from boreholes located in the area of SW Poland were selected for petrography, whole rock geochemistry and detrital zircon $\mathrm{U}-\mathrm{Pb}$ dating. The results show abrupt change in detrital zircon $\mathrm{U}-\mathrm{Pb}$ provenance, between strata that have been classified as Mississippian (L. Carboniferous) and Pennsylvanian (U. Carboniferous) based on previously published miospore zonation. The Pennsylvanian rocks (from the boreholes of Września-IG1 and Siciny IG1) bear a significant population of zircon grains with Lower Carboniferous ages (350-330 Ma), while such a zircon population is absent in Lower Carboniferous rocks (from the boreholes of Paproć-29 and Kobylin 1). The absence of Moscovian to Asselian zircons that are otherwise known from the adjacent areas with zirconbearing volcanic activity, suggests that the studied Pennsylvanian sediments represent the lower part of Upper Carboniferous. The presented data indicate abrupt provenance change that occurred in the source areas at the Mississippian-Pennsylvanian turn, and that was probably caused by changes in the tectonic architecture of the Variscan Orogen. This tectonic changeover resulted in exhumation and erosion of the Lower Carboniferous rock complexes and manifested itself by recycling of the Lower Carboniferous zircon into Upper Carboniferous strata.
\end{abstract}

Keywords Variscan Externides · U-Pb dating · Provenance - Variscides exhumation · Carboniferous strata of SW Poland · Rheno-Hercynian zone

Electronic supplementary material The online version of this article (https://doi.org/10.1007/s00531-020-01894-w) contains supplementary material, which is available to authorized users.

Urszula Zagórska

ulajonkis@wp.pl; zagorska@inig.pl

1 Oil and Gas Institute - National Research Institute, Lubicz 25A, 31-503 Kraków, Poland

2 Institute of Geology, Czech Academy of Sciences, Rozvojová 269, 16500 Praha, Czech Republic

3 Institute of Geological Sciences, Jagiellonian University, Gronostajowa 3a, 30-387 Kraków, Poland

4 Polish Oil and Gas Company (POGC)/Exploration and Production Branch in Warsaw, Bohaterów Westerplatte 15, 65-034 Zielona Góra, Poland

\section{Introduction}

Recent research describes the Variscan orogeny as a multistage collisional process related to the Late Paleozoic closure of a number of oceanic basins between the colliding Laurussia and Gondwana and resulting in the formation of the orogen stretching from Western to Central Europe (Franke et al. 2017; Mazur et al. 2010a). The easternmost part of the Variscan orogenic front in Europe occupies the SW territory of Poland, while the foreland basin stretches further eastwards to Ukraine. The Polish part of the orogen consists of metamorphosed volcanic and sedimentary Internides, i.e. the Sudetes, and thrust-faulted Externides composed of sedimentary sequence deposited in a proximal part of then developing foreland basin (Mazur et al. 2006b) (Fig. 1). The Externides, (also called the Wielkopolska Externides) currently deeply buried under the Permo-Mesozoic sedimentary 


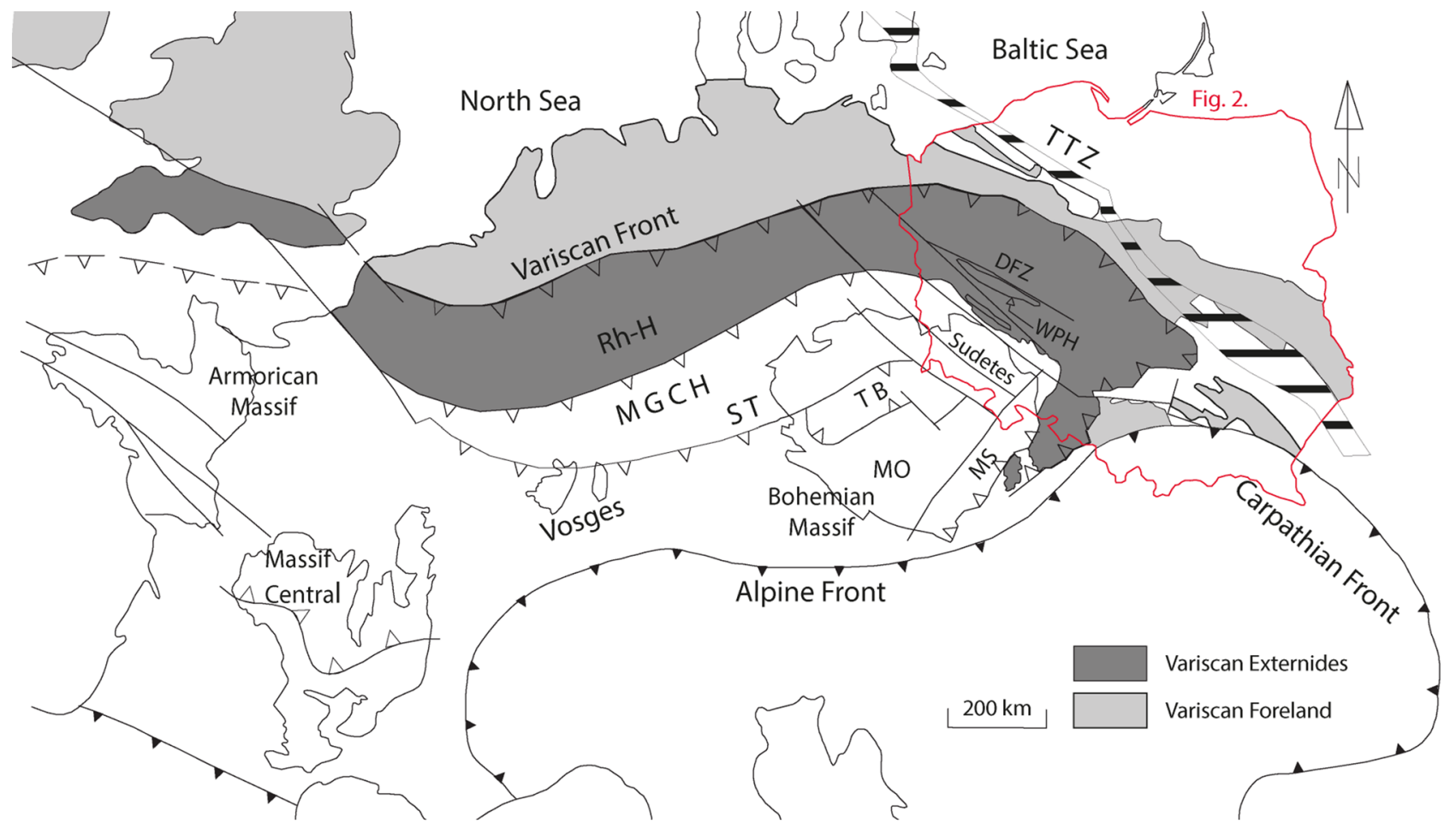

Fig. 1 The Variscan Externides in Europe. DFZ Dolsk Fault Zone, $M G C H$ Mid-German Crystalline High, $M O$ Moldanubian, $M S$ Moravo-Silesian, $R h-H$ Rheno-Hercynian, $S T$ Saxothuringian, TB

cover, gradually continue into the late Carboniferous rocks of foreland basin that are mostly undisturbed by Variscan tectonism.

The history of the Variscan orogen exhumation and tectonic evolution cannot be easily reconstructed based only on the study of metamorphic and magmatic rocks, because of the high thermal overprint as well as the deep erosional cut in most of the accessible parts of the orogen. However, the crucial information can be obtained from the detrital material of the sedimentary rocks deposited in the coeval foreland basin developing along the rising mountain ridge. Orogenic processes in the eastern part of the Variscan belt are especially poorly recognised because of their complexity and lack of rock outcrops. Similarly the tectonics, provenance and age of the Variscan Externides rocks and the foreland basin rocks in the easternmost part of the orogen are still a matter of an ongoing discussion (Franke et al. 2017), as the rock material is only accessible from deep boreholes. The available geochronological data on the erosional history is scarce and does not allow to fully reconstruct the timing of provenance changes in the easternmost parts of the Variscides (Żelaźniewicz et al. 2003; Mazur et al. 2006a, 2010b). Besides the importance for the understanding of the geological evolution of the Variscan orogen, the Carboniferous rocks in the area of
Teplá-Barrandian, TTZ Teisseyre-Tornquist Zone, WPH WolsztynPogorzela High, Compiled after: Mazur et al. (2006b), Żelaźniewicz et al. (2011) and Krzywiec et al. (2017)

SW Poland also represent significant source and reservoir rocks for hydrocarbon deposits exploited in the area nowadays.

A recent revision of the Carboniferous palynospore zones (Górecka-Nowak 2007, 2008) improved the stratigraphic subdivision in the area of the SW Poland (Variscan Externides and foreland) compared to earlier sketchy and very general classification (e.g. Krawczyńska-Grocholska 1975). As the material for biostratigrapic studies is not always available and palynospores are poorly preserved (Górecka-Nowak 2007, 2008; Fig. 3 - stratigraphic profiles), the need has emerged to employ an alternative method of rock stratigraphic correlation for both scientific and economic purposes. The aim of this study was to correlate the zircon $\mathrm{U}-\mathrm{Pb}$ sedimentary provenance analysis with the results of palynological research, to track changes occurring over time in detritus provenance as well as to constrain timing of the Variscides exhumation in the eastern flank of the orogen. Moreover the discrimination between Lower and Upper Carboniferous strata would be particularly important for hydrocarbon exploration, allowing the horizontal correlation between boreholes in cases where monotonous sandstone formations lack biostratigraphic information. 


\section{Geological setting}

The Variscan orogeny is a common term for a set of the Middle and Late Paleozoic tectonometamorphic events (Kroner et al. 2008), associated with the amalgamation of paleocontinents of Laurussia (formed from earlier: Laurentia and Baltica) and Avalonia with the Armorican Terrne Assemblage and northern part of Gondwana. (e.g. Matte 2001, Winchester 2002, Franke et al. 2017).

The eastern flank of the European Variscides is by far the most complicated part of the orogen. The apparent boundaries between tectonostratigraphic units of the Variscides correspond to the main sutures, transitional faults or shear zones. In the Polish part of the orogen, the following zones are distinguished (Fig. 1): the Tepla-Barrandian, the Saxo-Turingia, the Mid-German Crystalline High (all three zones can be traced in the Sudetes), and eventually, the Variscan Externides-mostly interpreted to be part of the Rheno-Hercynian Zone (Oberc 1987; Cwojdziński and Żelaźniewicz 1995) presumably underlain by phyllites of the Northern Phyllite Zone (NFZ) (Franke et al. 2017). It has not yet been fully confirmed whether zones identified in Germany have their continuation in the Polish part of the Variscan front (Żelaźniewicz et al. 2003).

Sedimentation of the Variscan Externides in this eastern part of the orogen was most probably controlled by tectonometamorphic evolution as well as exhumation of igneous rocks within the contiguous Bohemian Massif and its NE margin, i.e. the Sudetes. The following lithotectonic units can be distinguished within the Bohemian Massif: the Saxo-Thuringian Zone, the Teplá-Barrandian Unit, the Moldanubian Zone, the Moravo-Silesian Zone and the Brunovistulicum. The Saxo-Thuringian Zone is composed of Neoproterozoic sedimentary rocks (interpreted as the back-arc/retro-arc Cadomian system; Kroner et al. 2007; Linneman and Romer 2002) intruded by Late Neoproterozic - Early Cambrian granitoids. This rock sequence is unconformably overlain by Late Paleozoic volcanic and sedimentary rocks of the passive margin (McCann 2008). Both units were metamorphosed during Variscan orogenic processes. The subduction of Saxo-Thuringian Zone under the Teplá-Barrandian Unit from the Late Devonian until the Early Carboniferous (Krawczyk et al. 2000) resulted in metamorphic changes and the formation of a magmatic arc (Žák et al. 2014). Carboniferous granite bodies are the youngest rocks in the Saxo-Thuringian Zone and mark the final stage of the orogeny and amalgamation of the individual units of the Bohemian Massif. The Teplá-Barrandian Zone is composed of Neoproterozoic basement, hosting Cambrian-Ordovician plutonic bodies. Cambrian to Middle Devonian volcano-sedimentary rocks unconformably lie on top of this sequence. The NW part of the
Teplá-Barrandian is interpreted as an active margin both during the Cadomian and Variscan orogeny (Dörr et al. 2002; Žák et al. 2014; Hajná et al. 2017). South-eastern flank of the Teplá Barrandian is occupied by voluminous igneous plutons (chiefly calc-alkaline granitoids) of the Central Bohemian Plutonic Complex. The Plutonic Complex evolved as a continental magmatic arc in the Tournaisian-Visean times (Janoušek et al 2010; Dörr and Zulauf 2010). The Moldanubian Zone occupying the S and SE part of the Bohemian Massif is mainly composed of medium to high-grade metamorphic rocks of Neoproterozoic to Early Palaeozoic origin, partially interpreted as orogenic roots (Schlumann et al. 2005). The main highgrade metamorphic event affecting the Moldanubian rocks occurred at 340 Ma (e.g., Janoušek and Holub 2007; Jastrzębski et al. 2019). The metamorphic rocks of the Moldanubian Zone are intruded by numerous ultrapotassic melasyenitoids/melagranitoids (so-called durbachites) aged 343-335 Ma and Moldanubian Batholith granitoid bodies dated to Serpukhovian (331-323 Ma) Friedl et al. (1996) vide Franke (2000). Detailed descriptions of the geology of the Bohemian Massif can be found in articles by Dörr et al. (2002), Finger et al. (2007), Janoušek and Holub (2007), Pertoldová et al. (2010), Žák et al (2014) and Jastrzębski et al. (2015).

This study focuses on Variscan Externides rocks representing a syn- to postorogenic sedimentary succession of Carboniferous age, often interpreted as turbidite sequence (e.g., Ricken et al. 2000; Mazur et al. 2006b) or Culm facies (Wierzchowska-Kicułowa 1984) and overlying molasses deposit. The Variscan Externides include fold-thrust belt developed NE from Odra Fault Zone (Fig. 2), as well as well as less or non-deformed rocks deposited further to NE in the area of the Variscan Fordeep (Żelaźniewicz et al. 2011). The foreland basin rocks continuing further to the north and east from the Variscan orogenic front are mostly undeformed by the Variscan orogeny. Orogenic front itself having gradual character is difficult to trace (Karnkowski 2008). The most distinct tectonic structure in the area of the Variscan Externides is the Dolsk Fault Zone (Fig. 2), interpreted as the SW boundary of the Trans-European Suture Zone by Dadlez (2006).

The studied area represents a tectonically deformed part of the Variscan Externides, described as an external foldthrust belt. Deformation of the Variscan external zone in Poland have presumably reached its peak intensity by the late Carboniferous (Westphalian C), (Mazur et al. 2003). This sedimentary complex consists of a thick (exceeding $2.5 \mathrm{~km}$ ) flysch sequence and a younger molasse association (Grocholski 1983). Flysch sequence depositional environment has been described as submarine alluvial fans produced by: "(1) density currents, (2) gravitational flows and (3) pelagic sedimentation" (Mazur et al. 2003). The underlying 


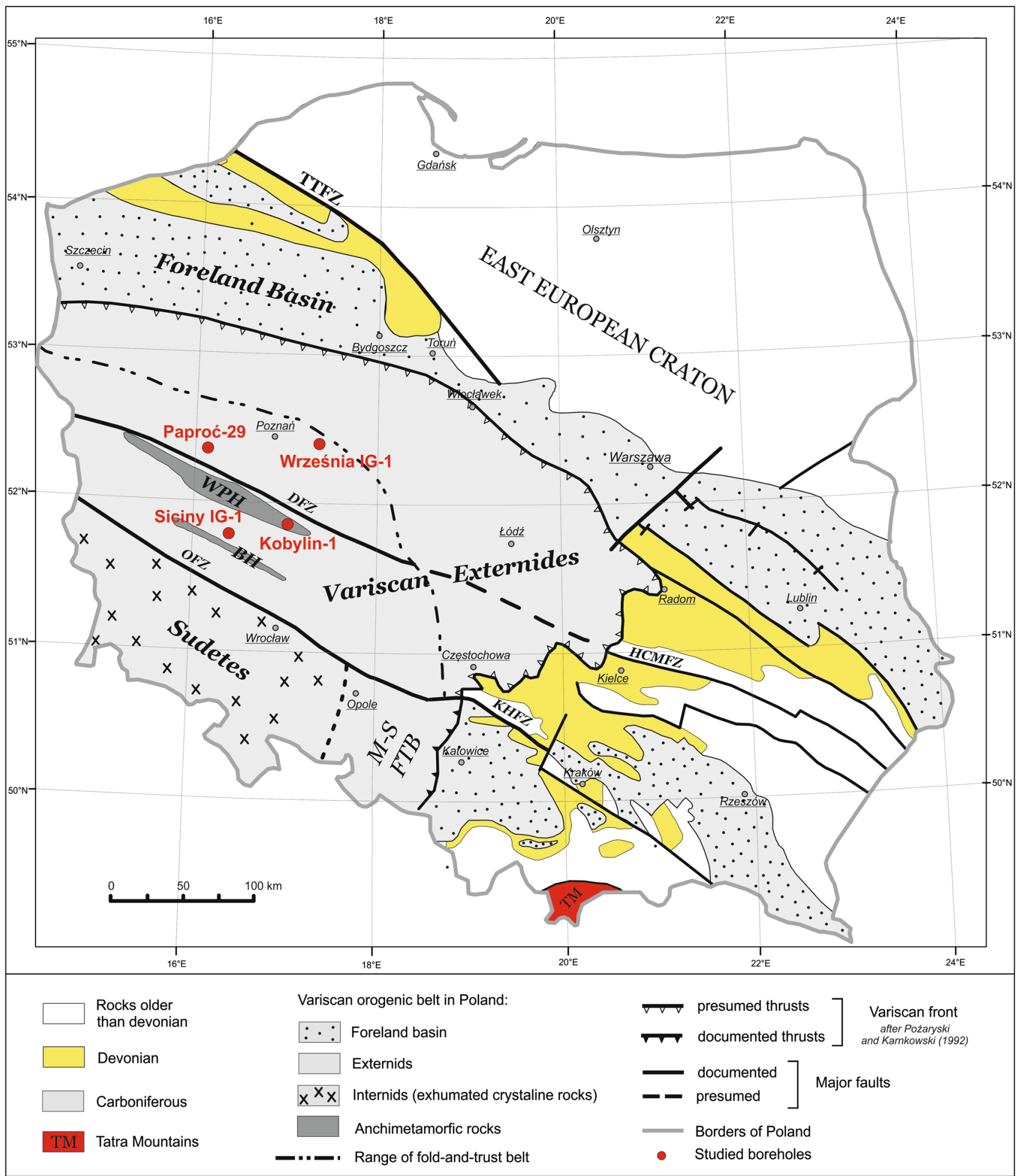

Fig. 2 Present day extent of Carboniferous strata on the area of Poland. Red dots show location of studied boreholes. WPH Wolsztyn-Pogorzela High, BH Bielawy High, M-S FTB Moravian-Silesian Fold-and-Thrust Belt, TTFZ Teisseyre-Tornquist Fault Zone, the northern boundary of the Trans-European Suture Zone, DFZ Dolsk Fault Zone, OFZ Odra Fault Zone, KHFZ Kraków-Hamburg Fault Zone, HCMFZ Holly Cross Mountains Fault Zone, TM Tatra Mountains. After Żelaźniewicz et al. (2011) - changed 
sequence reached by the drills in the Wolsztyn-Pogorzela High and the Bielawy High is represented by anchimetamorphic rocks of probably the Upper Devonian age (Haydukiewicz et al. 1999). The metamorphic overprint reached its peak at $340 \mathrm{Ma}$ (Żelaźniewicz et al. 2003). The occurrence of phyllites underlying Carboniferous strata led Franke et al. (2017) to link the area of the Wolsztyn-Pogorzela and Bielawy Highs with the Northern Phyllite Zone. Contrary to that, Żelaźniewicz et al. (2003) defined a separate Wielkopolska terrane as a discrete block belonging to the Armorican Terrane Assemblage.

The exact extent of foreland rocks and the Variscan orogenic front (Fig. 2) are not known in detail (Karnkowski 2008) especially because they were later affected by various processes. The sedimentary foreland basin rocks were partially incorporated in the fold-thrust belt as well as tectonically deformed in the Upper Carboniferous and Permian times.

Studies conducted in the $70 \mathrm{~s}$ of the twentieth century describe Carboniferous rocks of Varican Externides as a Lower Carboniferous (mostly Visean and Lower Tournaisian) flysch sequence in the eastern part of the ForeSudetic area and possibly Namurian in the area of KaliszCzęstochowa (Deczkowski 1977; Krawczyńska-Grocholska and Grocholski 1976a). Later, the Upper Visean and Namurian (to Westphalian) rocks were identified in a few boreholes in the area between Wrocław and Poznań based on the occurrence of Goniatites and miospores, respectively (Wierzchowska-Kicułowa 1984 and pub. cited therein). The top of the flysch sequence is terminated by up to a $500 \mathrm{~m}$ thick sequence of Westphalian B/C to Stephanian molasse (Wierzchowska-Kicułowa 1984). Nevertheless, the palynostratigraphy often gave inconsistent age determinations (Krawczyńska-Grocholska 1979, 1980; vide Wierzchowska-Kicułowa 1984; Górecka et al. 1977a; Karnkowski and Rdzanek 1982a) and the earlier subdivision of Carboniferous rocks of the Variscan Externides is now being revised.

\section{Sample description}

Analyses were conducted on 8 samples of medium- to very fine-grained sandstones from four boreholes: Siciny IG 1, Września IG 1, Paproć 29 and Kobylin 1. Sample depths and available stratigraphic position constraints are listed in Table 1 and Fig. 3. The Września IG 1 and Paproć 29 wells are located NE of the Wolsztyn-Pogorzela High, while Siciny IG 1 is situated SW of this structure. The borehole Kobylin 1 is located in the SE part of the Pogorzela High (Fig. 2). Sampling in the well profile was determined by the availability of the core material and done as close as possible to the intervals with known palynostratigraphy.

\section{Methods}

\section{Mineralogy and geochemistry}

One thin section was prepared for each analysed sample. Microscopic observations of samples were carried out with the use of a NIKON ECLIPSE E600 POL polarising microscope at the Institute of Geological Sciences of the Jagiellonian University in Kraków.

Quantitative mineral analysis was conducted by the Rietveld method with the application of the SiroQuant program, which is useful for analysing samples containing clay minerals. The quantitative measurements were done on a Panalytical X'Pert Pro diffractometer with a fast detector (Real Time Ultra Strip X'Celerator). The applied measurement parameters were as follows: $40 \mathrm{kV}$ voltage, $40 \mathrm{~mA}$ current, the step-width of $0.02^{\circ} 2 \Theta$ and the angular range

Table 1 Sample list with depth and biostratigraphy (after Górecka-Nowak 2007, 2008)

\begin{tabular}{|c|c|c|c|c|c|}
\hline Sample & Borehole & Depth $[\mathrm{m}]$ & Sample macroscopic description & Biostratigraphy constrains & International chronostratigraphy \\
\hline 17336 & Siciny IG 1 & 2263.50 & Dark grey fine-grained sandstone & Westphalian $\mathrm{C}(?)^{\mathrm{a}}$ & Moscovian \\
\hline 17341 & Siciny IG 1 & 2574.50 & $\begin{array}{l}\text { Dark grey very fine-grained sandstone } \\
\text { laminated with blackish mudstone }\end{array}$ & Upper Namurian A $(?)^{\mathrm{a}}$ & Serpukhovian - Bashkirian turn \\
\hline 17342 & Siciny IG 1 & 2684.50 & Grey fine-grained sandstone & Upper Namurian A & Serpukhovian - Bashkirian turn \\
\hline 17352 & Września IG 1 & 4952.50 & $\begin{array}{l}\text { Dark grey very fine-grained sandstone } \\
\text { laminated with blackish mudstone }\end{array}$ & Not older than Westphalian D & Not older than upper Moscovian \\
\hline 18268 & Paproć 29 & 2926.00 & $\begin{array}{l}\text { Light grey medium to fine-grained } \\
\text { sandstone }\end{array}$ & Lower Namurian A $(?)^{\mathrm{a}}$ & Lower Serpukhovian \\
\hline 18279 & Paproć 29 & 3278.80 & $\begin{array}{l}\text { Light grey medium to fine-grained } \\
\text { sandstone }\end{array}$ & Lower Namurian A & Lower Serpukhovian \\
\hline 19686 & Kobylin 1 & 2261.30 & Grey fine-grained sandstone & $?$ & $?$ \\
\hline 19704 & Kobylin 1 & 2857.25 & Grey fine-grained sandstone & $?$ & $?$ \\
\hline
\end{tabular}

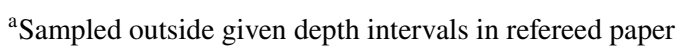


Fig. 3 Setting of chronostratigraphical and lithological profiles with palynological data after Górecka-Nowak (2007, 2008). Carboniferous miospore zonation based on Clayton et al. (1977) and Owens et al. (2004). The chronostratigraphy based on International Stratigraphic Chart, version 2020/01 https:// www.stratigraphy.org/ICSchart/ ChronostratChart2020-01.pdf Sampling depths of six samples are marked by diamonds in lithologic profiles

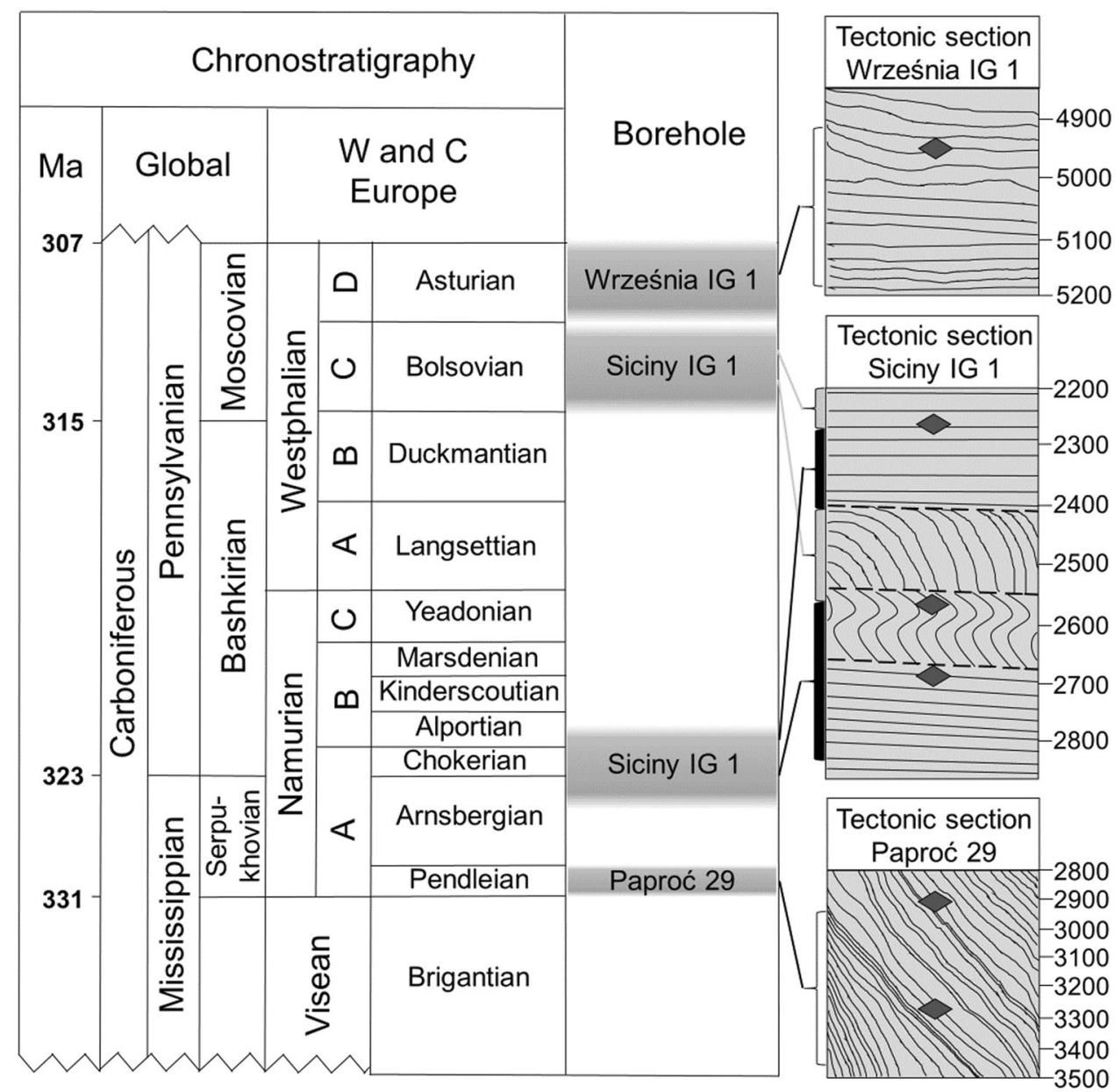

from $5^{\circ}$ to $65^{\circ} 2 \Theta$. Preparations were made according to the method introduced by Środoń et al. (2001). Prior to grinding, zincite $(\mathrm{ZnO})$ is added to samples as an internal standard to obtain full homogenisation. Samples are ground for $5 \mathrm{~min}$ in a McCrone micronising mill to reduce the grain size to $<10 \mu \mathrm{m}$. Measurements are conducted on random preparations prepared by side-loading.

Geochemical analysis of major and trace elements was commissioned from the certified Actlabs Laboratory (Canada). The applied ICP-MS and ICP-OES methods were preceded by fusion with lithium borate. The samples were milled to a powder fraction in agate milling bowls.

\section{LA-ICP-MS U-Pb zircon dating}

Zircon grains for $\mathrm{U}-\mathrm{Pb}$ age determination were separated by standard procedure of magnetic and heavy liquid separation in the Well Log Department of Oil and Gas Institute - NRI, Kraków, Poland. Grains were handpicked without preference to ensure analysis of random population, then mounted in epoxy resin and polished to ca. half-thickness.
Cathodoluminescence images of zircons were obtained using an electron probe microanalyzer (EPMA) with field emission gun (FEG) electron source JXA-8530F by Jeol equipped with a cathodoluminescence detector (CL) at the Institute of Petrology and Structural Geology, Charles University in Prague, the Czech Republic. Morphology of selected zircon grains is mostly subrounded to rounded, rarely prismatic. Analysis of CL images allowed to choose suitable areas of zircon surface for laser ablation, free from cracks, inclusions etc. and to avoid mixed ages acquisition. Prior to $\mathrm{U}-\mathrm{Pb}$ analysis, the carbon coating was removed and the sample surfaces were cleaned with $2 \% \mathrm{HNO}_{3}$, deionized water, and ethanol.

About 100 points per sample were analysed to get statistically robust data showing full spectrum of material provenance. Samples were analysed at the Institute of Geology of the Czech Academy of Sciences, Prague, the Czech Republic using Thermo Scientific Element 2 sector field ICP-MS coupled to a $213 \mathrm{~nm}$ NdYAG NewWave laser The LA conditions of two separate analytical sessions were set to $25-30 \mu \mathrm{m}$ spot size (depending on the grain size in the analysed samples), laser energy of ca $5.7 \mathrm{~J} / \mathrm{cm}^{2}$, repetition rate of $5 \mathrm{~Hz}$, flow of 
the He carrier gas at $765 \mathrm{ml} / \mathrm{min}$. The in-house glass signal homogenizer (design of Tunheng and Hirata 2004) was used for mixing all the gases and aerosol resulting in smooth, spike-free signal. The timing of the individual analyses was set to $15 \mathrm{~s}$ of gas blank and $35 \mathrm{~s}$ of zircon ablation followed by $35 \mathrm{~s}$ of cell wash-out.

The dead-time correction of the instrument was done prior to the analysis using a suite of variably concentrated $\mathrm{U}$ solutions. The $\mathrm{U}$ and $\mathrm{Pb}$ signals from the ablated zircon grains were acquired in time resolved - peak jumping - pulse counting/analogue mode with 1 point measured per peak for masses ${ }^{204} \mathrm{~Pb}+\mathrm{Hg},{ }^{206} \mathrm{~Pb},{ }^{207} \mathrm{~Pb},{ }^{208} \mathrm{~Pb},{ }^{232} \mathrm{Th},{ }^{235} \mathrm{U},{ }^{235} \mathrm{U}$, and ${ }^{238} \mathrm{U}$. Due to a non-linear transition between the counting and analogue (attenuated) acquisition modes of the ICP instruments, the raw data were pre-processed using a purpose-made Excel macro. As a result, the intensities of ${ }^{238} \mathrm{U}$ were left unchanged if measured in a counting mode and recalculated from ${ }^{235} \mathrm{U}$ intensities if the ${ }^{238} \mathrm{U}$ was acquired in analogue (attenuated) mode. Data reduction was then carried out off-line using the Iolite data reduction package version 3.0 with VizualAge utility (Petrus and Kamber 2012). Full details of the data reduction methodology can be found in Paton et al. (2010). The data reduction included correction for gas blank, laser-induced elemental fractionation of $\mathrm{Pb}$ and $\mathrm{U}$ and instrument mass bias. For the data presented here, blank intensities and instrumental bias were interpolated using an automatic spline function while down-hole interelement fractionation was corrected using an exponential function. No common $\mathrm{Pb}$ correction was applied to the data due to the high $\mathrm{Hg}$ contamination of the commercially available $\mathrm{He}$ carrier gas, which precludes accurate correction of the interfering ${ }^{204} \mathrm{Hg}$ on the very small signal of ${ }^{204} \mathrm{~Pb}$ (common lead). Primary concentrations of common $\mathrm{Pb}$ in zircon are considered very low and were controlled by observing the ${ }^{206} \mathrm{~Pb} /{ }^{204} \mathrm{~Pb}$ (radiogenic/common lead) ratio. Analyses with low values were examined (if present) in more detail.

Residual elemental fractionation and instrumental mass bias were corrected by normalization to the natural zircon reference material Plešovice (Sláma et al. 2008). Zircon reference materials 91500 (Wiedenbeck et al. 1995) and GJ-1 (Jackson et al. 2004) were periodically analysed during the measurements for quality control. The mean Concordia age values of $1066 \pm 5 \mathrm{Ma}(2 \sigma)$ for 91500 (concordance MSWD $=1.03$, probability $=0.53$ ) and slightly discordant (concordance MSWD $=2.5$, probability $=0.11$ ) Concordia age of $603 \pm 4 \mathrm{Ma}(2 \sigma)$ for GJ-1 obtained from analyses performed over the courses of different analytical sessions correspond perfectly and are less than $1 \%$ within the published reference values $\left(91500:{ }^{207} \mathrm{~Pb} /{ }^{206} \mathrm{~Pb}\right.$ age of $1065.4 \pm 0.3 \mathrm{Ma}$, Wiedenbeck et al. 1995; GJ-1: ${ }^{206} \mathrm{~Pb} /{ }^{238} \mathrm{U}$ age of $600.5 \pm 0.4 \mathrm{Ma}$, Schaltegger et al. 2015 and ${ }^{207} \mathrm{~Pb} /{ }^{206} \mathrm{~Pb}$ age of $608.53 \pm 0.4 \mathrm{Ma}$, Jackson et al. 2004 respectively). The zircon $\mathrm{U}-\mathrm{Pb}$ ages are presented as probability density plots generated with the ISOPLOT program v. 3.70 (Ludwig 2008).

\section{Results}

\section{Sandstone mineralogy and geochemistry}

Representative microphotographs of all eight samples are compiled in Fig. 4. According to classification of Folk (1974), the studied sandstones are lithic or feldspathic (arkosic) greywacke, litharenite and sublitharenite. In all the studied samples, the grains of the particle size skeleton are poorly-rounded and, in general, moderately-sorted. Both in samples no. 17336 and 17341 (lithic greywackes) as well as in samples no. 17342 and 17352 (feldspathic/ arkosic greywackes), the grain skeleton is dispersed, and the intergrain contact straight. The particle size skeleton usually consists predominantly of lithoclasts and feldspar (potassium feldspar and plagioclase) but in addition includes monocrystalline quartz (Siciny IG 1, 17341) and sometimes, in some samples-biotite and carbonates (Września IG 1, 17352). Zircon and opaque minerals occur in trace amounts. In both, lithic and feldspathic greywackes, the cement is made of clay or silty-carbonate matrix and sometimes of pure carbonates.

Samples from the boreholes of Paproć 29 and Kobylin 1 represent litharenite and sublitharenite. The particle size skeleton in these samples is generally compact and the contacts between the grains are convex or straight-convex (Paproć 29, 18268). The composition of the grain framework is dominated by monocrystalline quartz with addition of muscovite, potassium feldspar, lithoclasts and partially chloritised biotite (Kobylin 1, 19704) as well as traces of zircon and tourmaline. Cement $(<15 \%)$ is of a contact corrosion type with mineralogical composition being carbonateclay and carbonate-quartz-clay (Paproć 29, 18268).

According to the results of quantitative X-ray diffraction data (Table 2), Siciny IG 1 samples and especially the Września IG 1 sample show high amount of clay minerals from the mica and illite group, accompanied by 5-9\% of chlorites. The quartz content varies from $27 \%$ in the Września IG 1 sample to almost $38 \%$ in sample no. 17336 from the Siciny IG 1 borehole. Potassium feldspar is also present in all samples ranging from $~ 9$ to $19 \%$ of the total volume.

The Paproć 29 and Kobylin 1 samples are characterised by strong domination of quartz $(\sim 66-82 \%)$ and subordinate micas and illitic material $(\sim 10$ to $\sim 25 \%)$. The Paproć 29 samples and sample no. 19686 from Kobylin 1 also contain up to $3.5 \%$ of kaolinite, while 19704 contains $~ 9 \%$ of chlorite.

The concentrations of major elements (Table 3) were used for a basic lithological classification of all samples. In 
Fig. 4 Microphotographs of thin sections in cross-polarized light. Siciny IG 1: a-17336, b-17341, c-17342; Września IG 1: d-17352; Paproć 29: e-18268, f-18279; Kobylin 1: g-19686, h-19704. Scale bar size is $100 \mu \mathrm{m}$
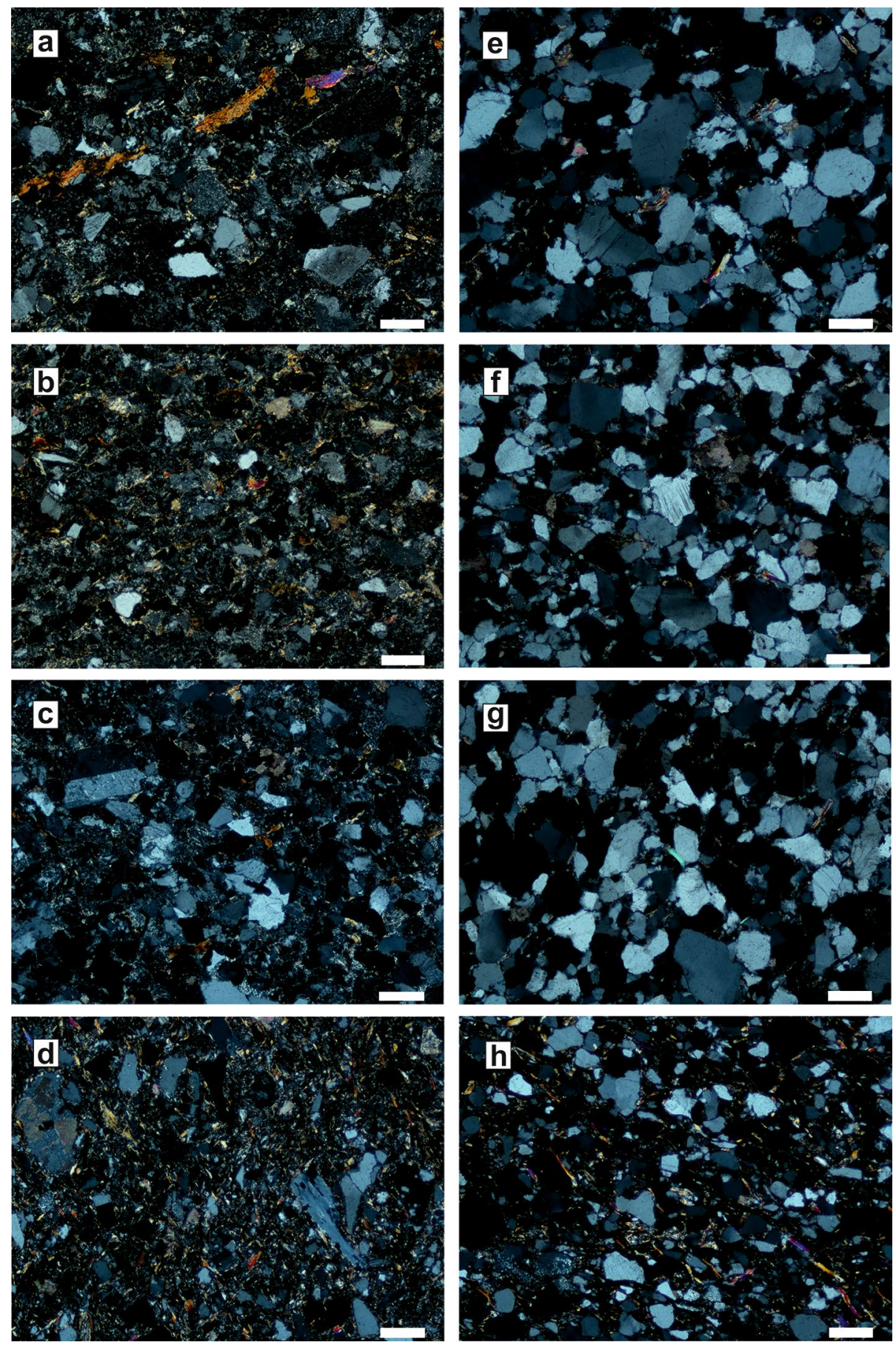

the sandstone-classification ternary diagram $\mathrm{Fe}_{2} \mathrm{O}_{3}+\mathrm{MgO}$ $-\mathrm{Na}_{2} \mathrm{O}-\mathrm{K}_{2} \mathrm{O}$ (Blatt et al. 1980), almost all the samples from the boreholes plot in the lithic sandstone field (Fig. 5). Only one sample from Siciny IG 1 fall in the arkose field.

In the $\log \left(\mathrm{Fe}_{2} \mathrm{O}_{3} / \mathrm{K}_{2} \mathrm{O}\right)$ vs. $\log \left(\mathrm{SiO}_{2} / \mathrm{Al}_{2} \mathrm{O}_{3}\right)$ diagram (Herron 1988), sandstone samples from the Paproć 29 and Kobylin 1 boreholes fall in the sublitharenite and litharenite fields (Fig. 5). The Siciny IG 1sandstones plot in the wacke field. The classification of the Września IG 1 sandstone into the shale field is in line with the presence of a thin shale laminae in this particular sample.

The trace element composition of studied sandstones (Supplement 1) was used to define the tectonic setting of the source rocks. The discrimination diagrams of Bhatia and Crook (1986), show difference between the groups of samples from Siciny IG 1 and Września IG 1 as compared to those from Paproć 29 and Kobylin 1 (Fig. 6). The samples from Siciny IG 1 and Września IG 1 predominantly plot 
Table 2 Quantitative X-ray diffraction results

\begin{tabular}{|c|c|c|c|c|c|c|c|c|c|c|c|c|c|c|c|c|c|}
\hline Sample & Borehole & $\begin{array}{l}\text { Depth } \\
{[\mathrm{m}]}\end{array}$ & $\begin{array}{l}\text { Qtz } \\
{[\%]}\end{array}$ & $\begin{array}{l}\mathrm{Pl} \\
{[\%]}\end{array}$ & $\begin{array}{l}\text { K-Fs } \\
{[\%]}\end{array}$ & $\begin{array}{l}\mathrm{Cal} \\
{[\%]}\end{array}$ & $\begin{array}{l}\text { Dol } \\
{[\%]}\end{array}$ & $\begin{array}{l}\text { Ank } \\
{[\%]}\end{array}$ & $\begin{array}{l}\mathrm{Hem} \\
{[\%]}\end{array}$ & $\begin{array}{l}\text { Py } \\
{[\%]}\end{array}$ & $\begin{array}{l}\mathrm{Gp} \\
{[\%]}\end{array}$ & $\begin{array}{l}\text { Ms + Ill } \\
{[\%]}\end{array}$ & $\begin{array}{l}\text { Ill/Sme } \\
{[\%]}\end{array}$ & $\begin{array}{l}\mathrm{Chl} \\
{[\%]}\end{array}$ & $\begin{array}{l}\mathrm{Kln} \\
{[\%]}\end{array}$ & $\begin{array}{l}\text { Sum } \\
{[\%]}\end{array}$ & $\begin{array}{l}\Sigma \text { clay } \\
{[\%]}\end{array}$ \\
\hline 17336 & Siciny IG 1 & 2263.50 & 37.7 & 11.3 & & 0.4 & & & & 3.0 & & 35.3 & 1.6 & 8.3 & 2.4 & 100.0 & 47.6 \\
\hline 17341 & Siciny IG 1 & 2574.50 & 30.5 & 9.3 & 2.0 & & 0.5 & & & 1.1 & & 45.5 & 1.7 & 7.7 & 1.7 & 100.0 & 56.6 \\
\hline 17342 & Siciny IG 1 & 2684.50 & 31.3 & 19.0 & 5.3 & & & 0.6 & & 9.3 & 1.1 & 27.9 & 0.7 & 4.8 & & 100.0 & 33.4 \\
\hline 17352 & Września IG 1 & 4952.50 & 26.8 & 12.1 & & & 1.0 & 1.7 & & & & 48.1 & 1.5 & 8.8 & & 100.0 & 58.4 \\
\hline 18268 & Paproć 29 & 2926.00 & 81.8 & & & & 2.0 & 1.3 & 1.9 & & & 9.7 & & & 3.3 & 100.0 & 13.0 \\
\hline 18279 & Paproć 29 & 3278.80 & 81.8 & & & & 1.6 & 0.8 & & & & 12.3 & & & 3.5 & 100.0 & 15.8 \\
\hline 19686 & Kobylin 1 & 2261.30 & 87.0 & & & & 0.9 & & & & & 10.1 & & & 2.0 & 100.0 & 12.1 \\
\hline 19704 & Kobylin 1 & 2857.25 & 66.4 & & & & & & & & & 24.7 & & 8.9 & & 100.0 & 33.6 \\
\hline
\end{tabular}

$Q t z$ quartz, $P l$ plagioclase, $K$-Fs potassium feldspar, Cal calcite, Dol dolomite, Ank ankerite, Hem hematite, $P y$ pyrite, Gp gypsum, Ms micas, Ill illite, Ill/Sme illite-smectite mixed layer, $C h l \mathrm{Fe}$-chlorite, Kln kaolinite, $\Sigma c l a y$ sum of clay minerals

close to the boundary between the active continental margin and the continental island arc field. The sandstones from Paproć 29 and Kobylin 1 on the adopted diagrams mostly fall outside the defined tectonic setting fields but tend to group close to the passive margin field in the Ti/Zr vs. La/ Sc diagram.

All the analysed samples show enrichment in LREE relative to HREE on the chondrite normalised spider diagram (Fig. 7). The LREE values decrease from La to Eu, where a negative anomaly is observed. The HREE pattern is generally flat, except for the sample no. 19686 from the Kobylin 1 borehole that shows a minor Tm, Yb, Lu increase. Two groups of samples can be observed on the chondrite normalised pattern. The group enriched in REE represented by samples from Września IG1 and Siciny IG1, and group with lower REE concentrations made up by Paproć 29 and Kobylin 1 samples. This division is also visible on other classification charts (Figs. 5, 6). One Kobylin 1 sample (19704) groups together with the Siciny IG1 and Września IG1 samples, which indicates the dissimilarity of this sample with the other Kobylin 1 and Paproć 29 samples, with regard to their composition of rare earth elements.

\section{$\mathrm{U}-\mathrm{Pb}$ detrital zircon dating}

Before U-Pb dating, the analysis of zircon internal structure was conducted based on the Atlas of Zircon Textures (Corfu et al. 2003). The majority of zircon grains from all eight samples are characterised mainly by oscillatory and sector zoning, interpreted as a strong domination of zircon of magmatic origin (Fig. 8). Very few grains show a xenocrystic core-mantle structure and some grains lack visible texture, which may indicate a metamorphic or magmatic origin. Metamorphic bright rims are sparsely present, as well as the whole grains with very bright cathodoluminescence, induced by a high uranium content.
The results of $\mathrm{U}-\mathrm{Pb}$ dating are presented in the Concordia diagram (Wetherill 1956a), available in Supplement 3, as well as in the probability density plots (PDPs) - Fig. 9. The data were filtered with the use of a common threshold of $10 \%$ discordance (Spencer et al. 2016). For ages younger than $1 \mathrm{Ga}$, the ${ }^{206} \mathrm{~Pb} /{ }^{238} \mathrm{U}$ dates were used, whereas for dates older than $1 \mathrm{Ga}$, we adopted the ${ }^{207} \mathrm{~Pb} /{ }^{206} \mathrm{~Pb}$ ages.

There is a clear distinction in the PDPs between the samples from the Siciny IG1 and Września IG1 boreholes as compared to the samples from Paproć 29 and Kobylin 1. The first two boreholes are characterised by the domination of a distinct population with ages of ca. 350-330 Ma (the Tournaisian to Visean). The Siciny IG1 samples show only few older grains ( 503 Ma, 415 Ma, 368-362 Ma). On the contrary, the Września IG1 sample contains a more significant input of older detrital material, in which UpperCambrian - Ordovician grains constitute a major population in the range between ca. 491-467 Ma, accompanied by two groups of the Neoproterozoic age of ca. $563 \mathrm{Ma}$ (3 grains) and $632 \mathrm{Ma}$ (3 grains) overlapping with each other on the Concordia plot (Supplement 3).

The distribution of detrital zircon ages significantly differs in the samples from Paproć 29 and Kobylin 1. In both boreholes, a broad Proterozoic age population 2200-900 Ma dominates in varying proportions. All four samples also contain a narrow age population of $\sim 445-440 \mathrm{Ma}$ (the Ordovician - Silurian turn), being their youngest age population, accompanied by a few grains with ages between $\sim 621$ and $496 \mathrm{Ma}$. Single grains of Archean age are also present in the Paproć 29 and Kobylin 1 samples.

The youngest zircon grains found in sample no.18268 from Paproć 29 form a homogenous cluster with the early Silurian age of ca. $440 \mathrm{Ma}$. The grains aged $\sim 500-440 \mathrm{Ma}$ also occur in the 18279 Paproć 29 sample. Both samples yielded abundant bimodal population ranging from ca. 1800 to $1400 \mathrm{Ma}$ and $1200-1100$ to $950 \mathrm{Ma}$. The youngest grains found in the Kobylin 1 samples $(19,686$ and 


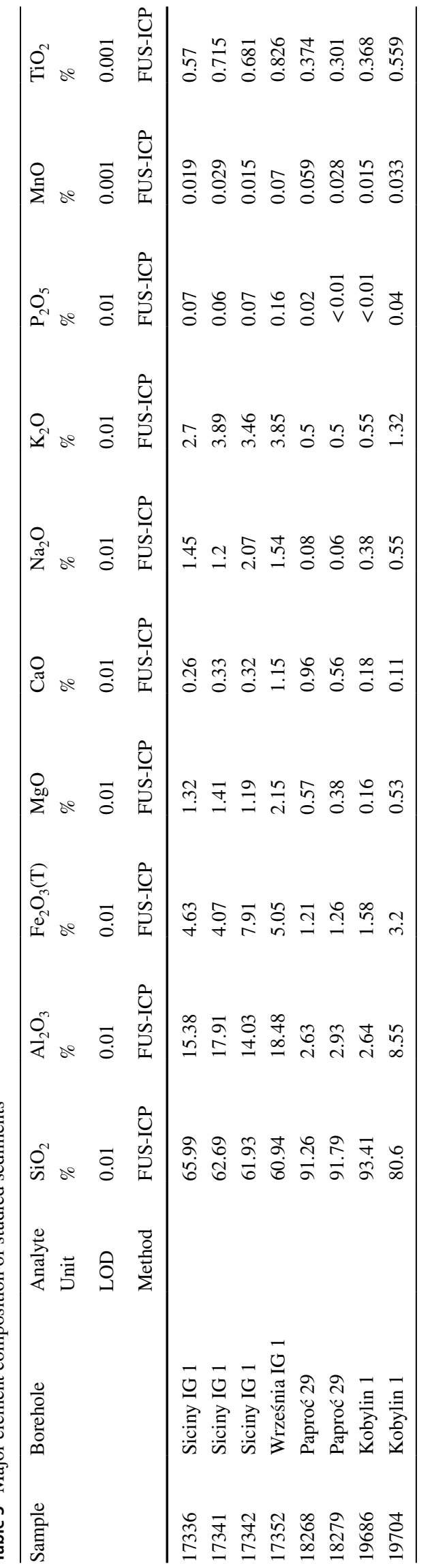

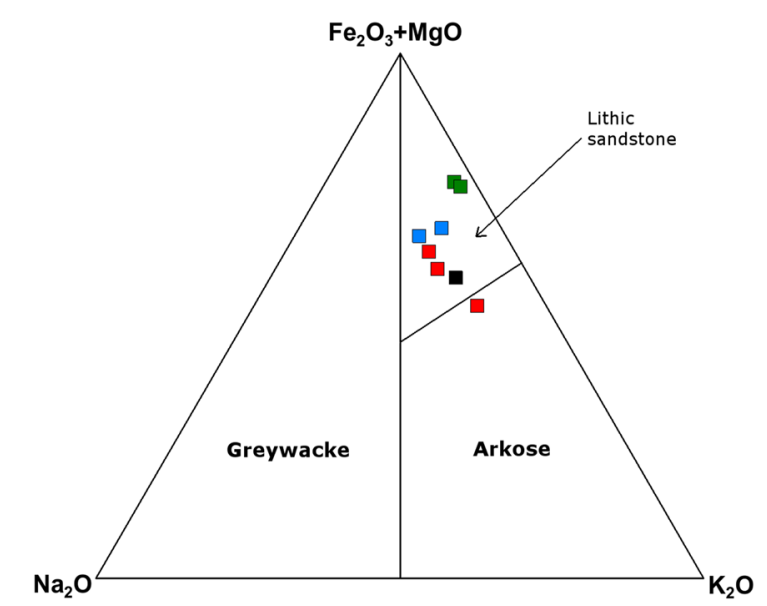

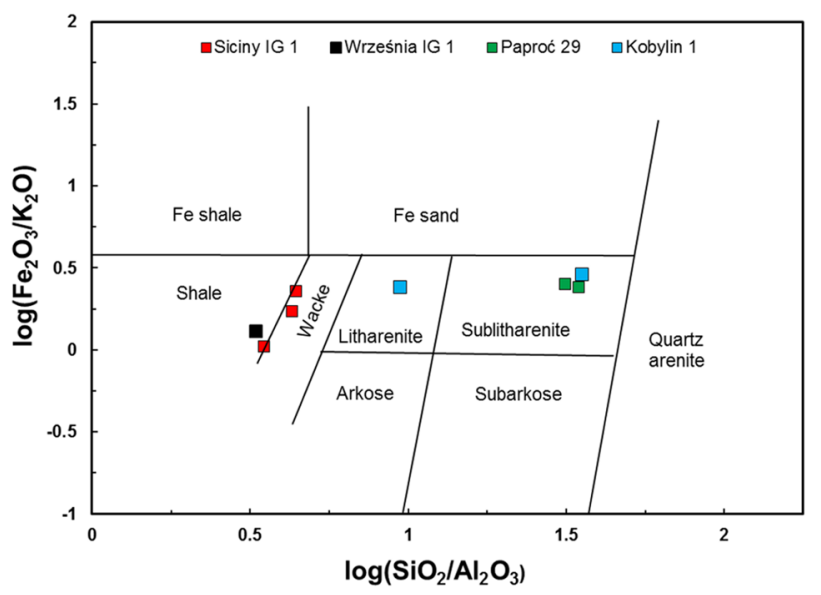

Fig. 5 Sandstone classification diagrams after Blatt et al. (1980) upper diagram; lower diagram after Herron (1988)

19,704) are equivalent to those from Paproć 29, with pooled ages $441 \mathrm{Ma}$ and $445 \mathrm{Ma}$, respectively. In general the zircon spectra from Kobylin 1 samples are very similar to Paproć 29 with abundant Proterozoic zircon grains in the range $2000-900$ Ma that can roughly be separated to two populations between ca. 1900 and1300 Ma and 1200-950. The complete LA-ICP-MS U-Pb data are available in Supplement 2.

\section{Discussion}

\section{Sediment provenance and stratigraphy}

To link the U-Pb data with the deposition age (Fig. 3), we have selected three boreholes with defined stratigraphic position (palynostratigraphy by Górecka-Nowak 2007, 2008). Only one of the analysed boreholes-Kobylin 1, recently drilled, has provided no biostratigraphic data. 

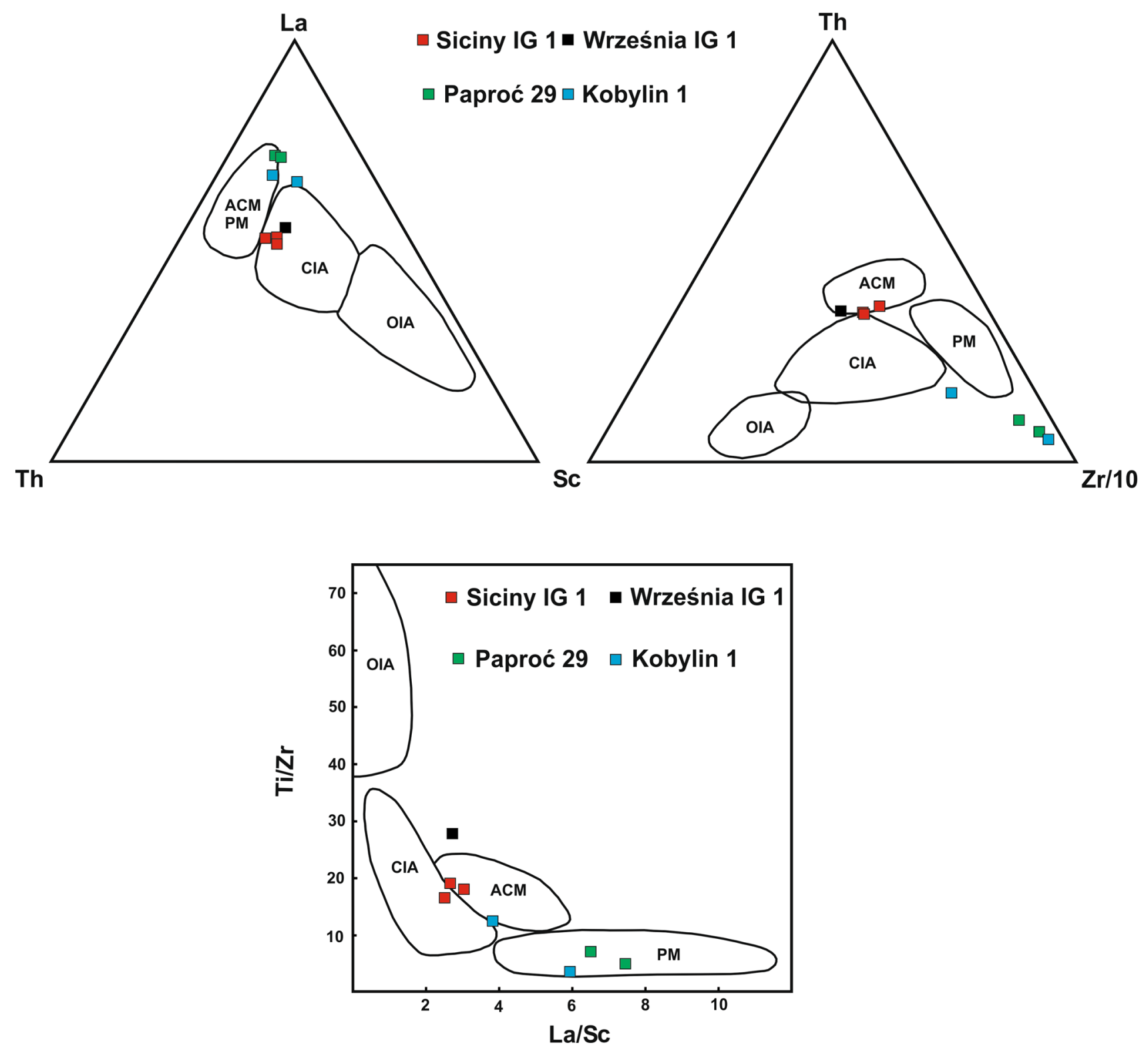

Fig. 6 Sandstone discrimination diagrams after Bhatia and Crook (1986) presenting detritus provenance according to tectonic setting. OIA Oceanic island arc, CIA Continental island arc, ACM Active continental margin, PM Passive margin

The palynostratigraphic age of the Carboniferous profile drilled in the Paproć 29 borehole is assigned to the Pendleian (the Namurian A), i.e. the Serpukhovian (GóreckaNowak 2007). However, Górecka-Nowak stresses the abundance of poorly preserved miospores and points to contamination with miospores from older rocks with ages spanning from the Upper Devonian to the Middle Mississippian. The detrital zircon $\mathrm{U}-\mathrm{Pb}$ spectra show a dominance of Proterozoic ages between ca 2.0 and $1.0 \mathrm{Ga}$ along with a subordinate zircon population from the Ordovician - Silurian turn. The Kobylin 1 samples are characterized by very similar zircon age spectra to those of the Paproć
29 samples, therefore we suppose they represent the same stratigraphic position.

The Siciny IG 1 and Września IG 1 samples provided different zircon $\mathrm{U}-\mathrm{Pb}$ age spectra from those characteristic for Paproć 29 and Kobylin 1. Two samples (17341 and 17342) from Siciny IG 1 come from an interval assigned to the Upper Arnsbergian - Alportian by Górecka-Nowak (2008), which corresponds to the Serpukhovian - Bashkirian turn (the Namurian A-B). This indicates a rapid switch in detrital material sources that occurred between the sedimentation of Carboniferous rocks drilled in the Siciny IG1-Września IG1 boreholes as compared to Paproć 29 and Kobylin 1. The 
Fig. 7 Chondrite normalised diagram. Chondrite values after Taylor and McLennan (1985)

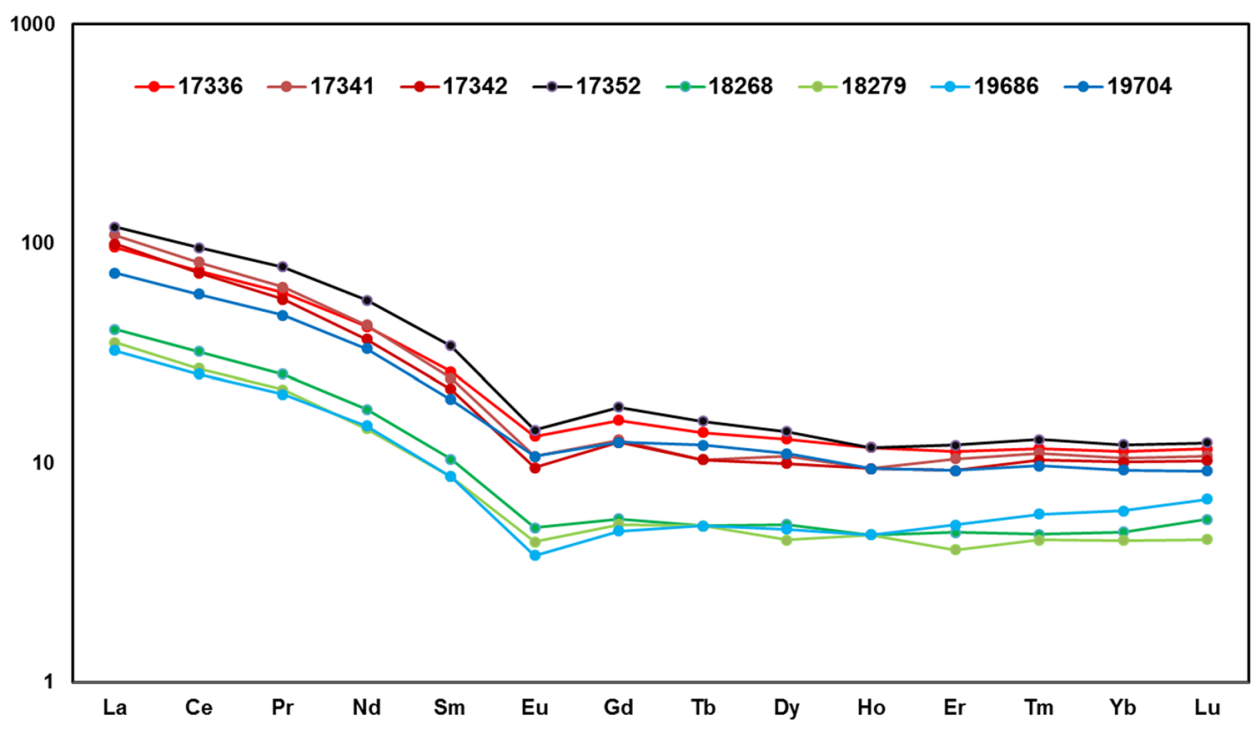

third sample (17336) with identical U-Pb zircon age spectrum, is biostratigraphycally equivalent to the younger Moscovian - Bolsovian miospore zone (the Westphalian C). The biozone interpretation was based on the youngest miospores present in the sample despite of examining abundant older taxa - Upper Devonian-Tournaisian and Upper Visean-Serpukhovian (Górecka-Nowak 2008).

The Września IG 1 sample, bearing very similar detrital zircon age spectra to those of Siciny IG 1 samples with abundant zircon population of 350-330 Ma, is located in the part of the profile defined by Górecka-Nowak (2008) as being "not older than the Asturian" (the Westphalian D) equivalent to the Moscovian. However, the Września IG 1 sample also contains a significant admixture of older detritus (ca. 450-650 Ma), indicating a slightly different position which allowed supplies from different sources. The occurrence of these older zircon ages in detrital material can be related to the borehole location, closer to the edge of Baltica. Based on this correlation, we can assume that since the beginning of the Lower Pennsylvanian, detrital material resulting from an erosion of ca 350-330 Ma (Lower-Middle Mississippian) old rocks was the dominating source of sedimentary material for the part of the external basin where these two boreholes are located.

Compared to earlier U-Pb dating (Mazur et al. 2010b, Fig. 10) of rock samples from Siciny IG 1 (based on 22 zircon grains), the late Devonian age population is missing in our data. The youngest grain population obtained by Mazur et al. (2010b) gave weighted mean average of $345.4 \pm 3.2 \mathrm{Ma}$ (for 10 grains), and was interpreted as the maximum depositional age for the Siciny IG1 sandstone. In this study we have analysed $\sim 100$ grains per sample and obtained a broader age range, i.e. 350-330 Ma for the youngest grains. There does not seem to be a single youngest population in the LA ICP-MS data and therefore we avoided defining the maximum depositional age. A few zircon grains of ca. $300 \mathrm{Ma}$ found in the Września IG1 sample (of 29 grains analysed in total) encouraged Mazur et al. (2010b, Fig. 10) to set its maximum depositional age to Westphalian D (Moscovian). In our dataset the concordant grains younger than $330 \mathrm{Ma}$ are absent. The distinct age population 350-330 Ma present in both the Siciny IG1 and the Września IG1 samples is interpreted as the record of intensive magmatic activity period in the source area.

The exact location of the analysed samples in the stratigraphic profile may be uncertain, particularly because of a low quality of miospore material available for the studies of Gorrecka-Nowak (2007, 2008), as stated therein. Especially questionable is the lack of younger $\mathrm{U}-\mathrm{Pb}$ zircon ages in Upper Carboniferous (Moscovian/Westphalian) rocks, coeval to the stratigraphic position.

Oplustil et al. (2016) showed the occurrence of abundant volcanic material in their studied Westphalian and Stephanian rocks of the Bohemian Massif, including zircon grains allowing to define the rock stratigraphic position and calibration of biozones. Tuff beds, analysed by Oplustil et al. (2016), gave 15 precise age determinations ranging from 314.2 to $297.1 \mathrm{Ma}$ (the Moscovian to the Asselian). Hereby, in the examined samples, Upper Carboniferous zircons are surprisingly absent. This might imply that rocks drilled in the Siciny IG1 and Września IG1 boreholes belong only to the lower part of Upper Carboniferous though igneous rocks of the Uppermost Carboniferous are also found in the Sudetes. 
Fig. 8 Examples of zircon grains internal structure (EMPA-CL) with corresponding $\mathrm{U}-\mathrm{Pb}$ ages. Rows from the top: Siciny IG1, Września IG 1, Paproć 29, Kobylin 1

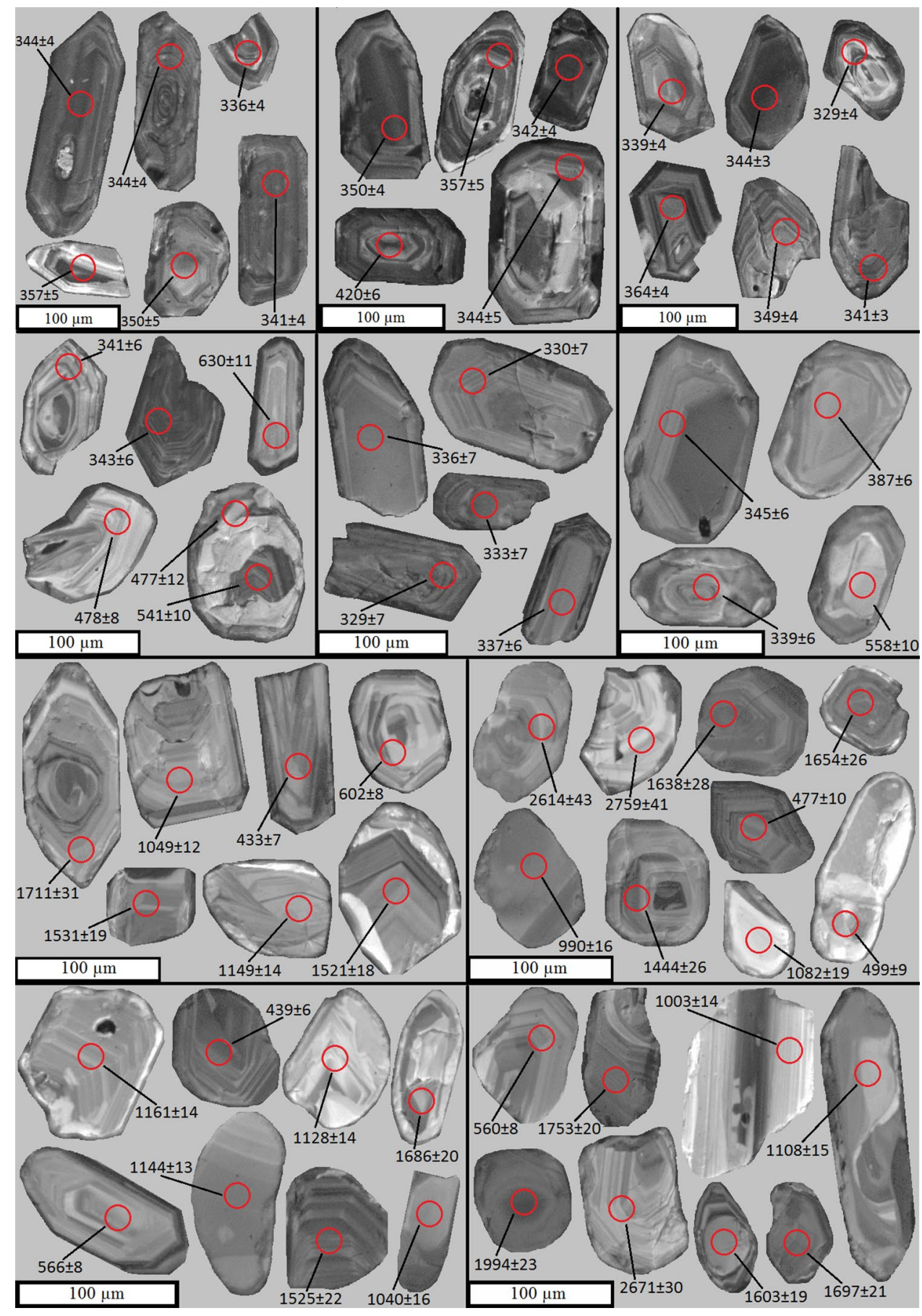

\section{Implications for regional geology}

The new data show a significant provenance change in Carboniferous strata of the Variscan foreland basin which occurred at the Mississippian - Pennsylvanian boundary (the Serpukhovian), in line with the division based on the miospore zonation. Although earlier petrographic studies indicated that the provenance changed in the Goniatites Zone, Go $\beta$ i.e. late Visean (Krzemiński 2005), we assume that the main provenance change probably took place in the late Serpukhovian.

Lower Carboniferous rocks contain mainly a detrital zircon age population characteristic of Baltican origin with prevailing Proterozoic ages between ca. 2100 and $900 \mathrm{Ma}$ (Friedl et al. 2000; Bogdanova et al. 2008). The closest part of the East European Platform need not have been solely the source for this material (Krzemińska et al. 2017), but the detritus might have also been derived from the Małopolska 

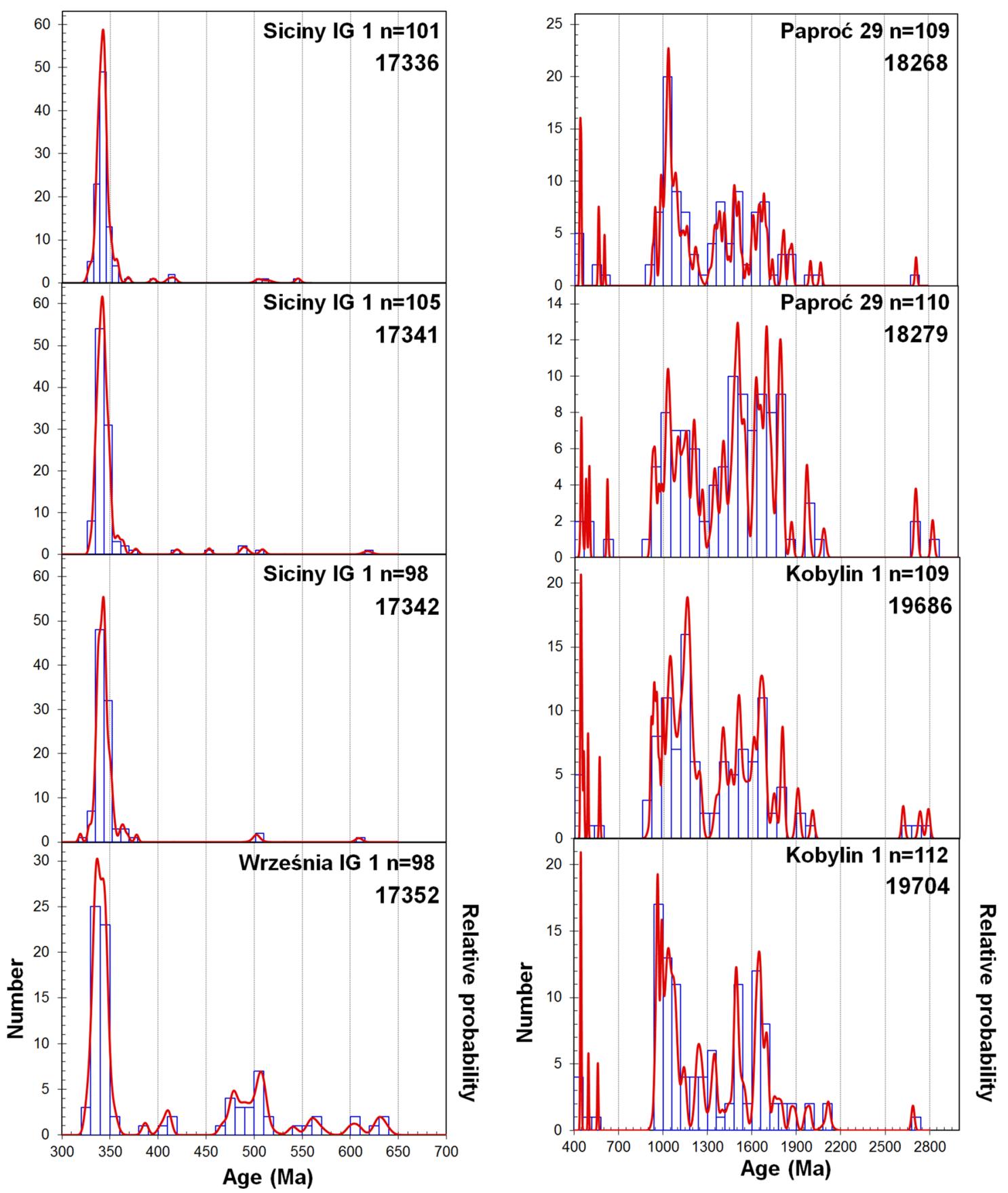

Fig. 9 Probability density plots of analysed samples. Few older grains were omitted for readability

Massif, where the Precambrian and Cambrian sequences bear a population of detrital zircon with similar age range (Żelaźniewicz et al. 2009, 2020). As yet, the age of the basement of the Variscan Basin in the Sudetes Foreland has not been documented either. Due to a high thickness of Late Paleozoic and Mesozoic rocks, the basement has not been drilled in any of the boreholes. Thinned Baltica's/East European Platform's margin could reach the Trans-European Suture Zone (TESZ) towards SW as far as the Odra Fault
(Żelaźniewicz et al. 2016). The possibility of a farther extent of Baltica's basement was proposed by Żelaźniewicz et al. (1997) and recently that model is further refined (Bayer et al. 2002; Malinowski et al. 2005; Żelaźniewicz et al. 2016; Mazur et al. 2015b, 2018). Provided that the southern limit of Baltica is further south, the detrital zircons of age ca. 2100-900 Ma might as well be recycled from the basement of the Variscan Foreland Basin.Upper Carboniferous rocks were fed mainly with Lower Carboniferous 




Fig. 10 Probability density plots of Siciny and Września samples analysed by Mazur et al. (2010b) - for comparison

(350-330 Ma) detrital material of Variscan magmatic origin. Differences in provenance of detrital material are also reflected in mineralogy and geochemistry (e.g. Fig. 5) of the analysed sandstones. The Lower Carboniferous samples from Paproć 29 and Kobylin 1 have arenitic composition, while the Upper Carboniferous samples from Siciny IG 1 and Września IG 1 were classified as graywackes. Trace element geochemistry places the Września IG1 and Siciny IG 1 sandstones in the geotectonic setting of an active continental or island arc, in contrast with Paproć 29 and Kobylin 1, the samples, which show affinity with passive margin geotectonic settings (Fig. 6). Continental magmatic arc origin of the Siciny IG 1 and Września IG 1 sandstones (as well as of rock material from neighbouring boreholes), was indicated in other petrography and geochemistry provenance studies (Krzemiński 2005; Mazur et al. 2010b).

As proposed by Mazur et al. (2010b), the Sudetes could be a potential source of Turnaisian - Visean detrital material (350-330 Ma). There is a number of such $\mathrm{U}-\mathrm{Pb}$ ages known from this part of Variscan orogen, e.g. the granitoids in the Kłodzko-Złoty Stok Region with ages 340-331 Ma (Mikulski et al. 2013), granitoids from the Niemcza Region dated at 342-336 Ma (Pietranik et al. 2013) or the age of 338 Ma obtained from a rhyolite from the Kłodzko Massif (Mazur et al. 2015a). However, similar dates are common within the entire Bohemian Massif. If material transport was possible from a wider area to the sedimentary basin formed in the Sudetes Foreland (the Variscan Externides of Wielkopolska), then the number of potential source rocks is very large. For example the age of the Central Bohemian Plutonic Complex zircon is very similar (ca. 350-330 Ma; Holub et al. 1997; Janoušek and Gerdes 2003; Dörr and Zulauf 2010) to the ones obtained from the studied Late Carboniferous rocks. It is related to the succession of pluton emplacement processes operating continuously between ca. 347 and $328 \mathrm{Ma}$ (Dörr and Zulauf 2010; Žák et al. 2005). Also in some parts of the Moldanubian Unit similar zircon ages $334 \mathrm{Ma}$ and $340 \mathrm{Ma}$ can be found (Siebel et al. 2005; Košler et al. 2013). However, at that time, the Sudetes may have already acted as an orographic barrier precluding such far transport. For this reason, the Sudetes should be primarily considered as potential source terrain.

The detrital zircons of Ordovician and Silurian age found in Lower Carboniferous samples (Paproć 29 and Kobylin 1 boreholes) could have been sourced from the RhenoHercynian Zone of the Variscan Orogen. Similar Silurian (to Devonian) ages (440-400 Ma), found in the Northern Phyllite Zone in Germany, were assigned to "the Silurian arc" by Franke and Onceken (1995). "The Silurian arc" was formed as a result of subduction of the Rheic Ocean crust and is interpreted as the Rheic Ocean suture. The remnants of the Silurian arc must have been eroded away at least by the end of the Lower Carboniferous and deposited in parts of the foreland basin, now building the Variscan Externides. The minor occurrence of $\sim 40$ Ma detrital zircon in the studied foreland rocks indicate that the Northern Phyllite Zone could have also continued to the Polish part of the orogen and might be represented by fyllites found in the basement of the Wolsztyn-Pogorzela High (Żelaźniewicz et al. 2003).

\section{Research application in hydrocarbon exploration}

The studied part of the Variscan Externides was affected by moderate to intense tectonic processes including thrusting, folding and formation of sedimentary sequence repetitions (Mazur et al. 2006b; Górecka-Nowak 2004). A complicated tectonic architecture causes difficulties in identifying horizons for hydrocarbon exploration purposes. The part of the Variscan Externides, the area under examination, is one of the most important regions of natural gas exploration in Poland, therefore, a reliable method for stratigraphic identification of rocks to be drilled is in need.

Reservoir rocks, being drilling targets, are mostly sandstone sequences, often poor in microfossils suitable for biostratigraphy. The employment of detrital zircon $\mathrm{U}-\mathrm{Pb}$ 
dating proved to be a very useful method for stratigraphic discriminations between the Lower and the Upper Carboniferous and opens up a new possibility for exploration. The identification of Upper Carboniferous strata is based on the occurrence of Lower Carboniferous zircon grains, while Lower Carboniferous rocks carry no Carboniferous imprint.

\section{Conclusions}

1 The East European Platform (Baltica; ca. 2000-950 Ma) and Upper Devonian to Lower Silurian (445-440 Ma) rocks, possibly coming from "the Silurian arc", were the primary sources of sediments for Lower Carboniferous rocks deposited in the foreland basin of the eastern part of the Variscides.

2 The Upper Carboniferous Externide rocks in the studied area were mainly sourced (since the Uppermost Sepurkhovian) with detrital material coming from a magmatic rocks of a Variscan affinity, the location of which is still uncertain. Applying the law of parsimony, we consider Sudetes as the most probable source of Mississippian zircon in the studied samples.

$3 \mathrm{U}-\mathrm{Pb}$ detrital zircon age spectra indicate a significant change in the source of sedimentary material between the Lower and Upper Carboniferous rocks in the Variscan Externides.

4 The change in provenance occurred in a relatively short period of time limited to (a part of?) the Sepurkhovian.

5 The shift in detritus source is most likely related to the rearrangement of the Variscan Orogen, i.e. the exhumation and massive erosion of Lower Carboniferous magmatic rocks since the Mississippian to the Pennsylvanian boundary.

6 Differences in the $\mathrm{U}-\mathrm{Pb}$ zircon age spectra allow to discriminate between Lower and Upper Carboniferous rocks in the area of SW Poland, which is a significant region for hydrocarbon exploration.

7 The age of the Upper Carboniferous rocks drilled in the boreholes of Siciny IG 1 and Września IG 1 could be determined as lower part of Upper Carboniferous, owing to the lack of zircons younger than $320 \mathrm{Ma}$, ubiquitous in Uppermost Carboniferous sediments.

Acknowledgements The authors thank A. von Quadt and another anonymous reviewer for their constructive reviews that helped improve the manuscript. The authors acknowledge also helpful reviews of Katarzyna Kołtonik This research was supported by the Polish Ministry of Science and Higher Education (Contract Number 0006/SW/16/01). Jiří Sláma was supported by the Academy of Sciences of the Czech Republic, institutional support to the Institute of Geology (ASCR, RVO 67985831).
Open Access This article is licensed under a Creative Commons Attribution 4.0 International License, which permits use, sharing, adaptation, distribution and reproduction in any medium or format, as long as you give appropriate credit to the original author(s) and the source, provide a link to the Creative Commons licence, and indicate if changes were made. The images or other third party material in this article are included in the article's Creative Commons licence, unless indicated otherwise in a credit line to the material. If material is not included in the article's Creative Commons licence and your intended use is not permitted by statutory regulation or exceeds the permitted use, you will need to obtain permission directly from the copyright holder. To view a copy of this licence, visit http://creativecommons.org/licenses/by/4.0/.

\section{References}

Bayer U, Grad M, Pharaoh TC, Thybo H, Guterch A, Banka D, Lamarche J, Lassen A, Lewerenz B, Scheck M, Marotta AM (2002) The southern margin of the East European Craton: new results from seismic sounding and potential fields between the North Sea and Poland. Tectonophysics 360:301-314. https://doi. org/10.1016/S0040-1951(02)00359-1

Bhatia MR, Crook KAW (1986) Trace element characteristics of graywackes and tectonic setting discrimination of sedimentary basins. Contrib Mineral Petrol 92:181-193. https://doi. org/10.1007/BF00375292

Blatt H, Middleton G, Murray R (1980) Origin of sedimentary rocks. Upper Saddle River, Prentice-Hall

Bogdanova SV, Bingen B, Gorbatschev R, Kheraskova TN, Kozlov VI, Puchkov VN, Volozh YuA (2007) The East European Craton (Baltica) before and during the assembly of Rodinia. Precambr Res 160:23-45. https://doi.org/10.1016/j.precamres.2007.04.024

Clayton G, Coquel R, Doubinger J, Gueinn KJ, Loboziak S, Owens B, Streel M (1977) Carboniferous miospores of Western Europe: illustration and zonation. Meded Rijks Geol Dienst 29:1-71

Corfu F, Hanchar JM, Hoskin PWO, Kinny P (2003) Atlas of zircon textures. In: Hanchar JM, Hoskin PWO (eds) Zircon. Min Soc Am Geochem Soc Rev Min Geochem 53:469-500 DOI: 10.2113/0530469

Cwojdziński S, Żelaźniewicz A (1995) Podłoże krystaliczne bloku przedsudeckiego. Przew. LXVI Zjazdu Pol Tow Geol, Wrocław 21-24.IX.1995. Rocznik Pol Tow Geol wyd spec 11-28.

Dadlez R (2006) The Polish Basin - relationship between the crystalline, consolidated and sedimentary crust. Geol Quarterly 50(1):43-58

Deczkowski Z (1977) Budowa geologiczna pokrywy permsko-mezozoicznej i jej podłoża we wschodniej części monokliny przedsudeckiej (obszar kalisko-częstochowski). Pr Inst Geol 82:1-63

Dörr W, Zulauf G (2010) Elevator tectonics and orogenic collapse of a Tibetan-style plateau in the European Variscides: the role of the Bohemian shear zone. Int J Earth Sci (Geol Rundsch) 99:299-325. https://doi.org/10.1007/s00531-008-0389-x

Dörr W, Zulauf G, Fiala J, Franke W, Vejnar Z (2002) Neoproterozoic to Early Cambrian history of an active plate margin in the TepláBarrandian unit-a correlation of U-Pb isotopic-dilution-TIMS ages (Bohemia, Czech Republic). Tectonophysics 352(1-2):6585. https://doi.org/10.1016/S0040-1951(02)00189-0

Finger F, Gerdes A, Janoušek V, René M, Riegler G (2007) Resolving the Variscan evolution of the Moldanubian sector of the Bohemian Massif: the significance of the Bavarian and the Moravo-Moldanubian tectonometamorphic phases. J Geosci 52:9-28. https://doi. org/10.3190/jgeosci.005

Folk RL (1974) Petrology of sedimentary rocks, 2nd edn. Hemphill Press, Austin 
Franke W (2000) The mid-European segment of the Variscides: tectonostratigraphic units, terrane boundaries and plate tectonic evolution Geological Society. Lond Special Public 179:35-61. https:// doi.org/10.1144/GSL.SP.2000.179.01.05

Franke W, Cocks LRM, Torsvik TH (2017) The Palaeozoic Variscan oceans revisited. Gondwana Res 48:257-284. https://doi. org/10.1016/j.gr.2017.03.005

Franke W, Oncken O (1995) Zur prädevonischen Geschichte des Rhenohercynischen Beckens. Nova Acta Leopoldina Neue Folge 71(291):53-72

Friedl G, Finger F, McNaughton NJ, Fletcher IR (2000) Deducing the ancestry of terranes: SHRIMP evidence for South America-derived Gondwana fragments in central Europe. Geology 28(11):1035-1038. https://doi.org/10.1130/00917613(2000)028<1035:DTAOTS > 2.3.CO;2

Friedl G, von Quadt A, Finger F (1996) Timing der Intrusion-tätigkeit im südböhmischen Batholith. In: Facultas- Universitätsverlag, 6. Symposium: Tektonik Strukturgeologie-- Kristallingeologie, Salzburg, pp 127-130.

Grocholski A (1983) The Carboniferous in southwestern Poland. Prz Geol 31(1983):351-356

Górecka T, Juroszek C, Karwowski L, Kłapciński J, Lorenc S, Mierzejewski M, Sachanbiński M, Ślusarczyk S (1977) The crystalline rocks and Carboniferous deposits of the Foresudetic Monocline, the Żary Pericline and the adjacent part of Foresudetic Block. Pr Nauk Inst Górn Polit Wrocl 22:9

Górecka-Nowak A (2004) Redeposition as an important factor affecting the results of biostratigraphic investigations - a case study from the Carboniferous sediments in the basement of the Fore-Sudetic Homocline. In: Muszer J (ed) XIX conference on palaeobiology and biostratigraphy, polish geological society, abstract volume. University of Wrocław, Wrocław, pp 21-23

Górecka-Nowak A (2007) Palynological con straints on the age of the Carboniferous clastic succession of SW Poland (Fore-Sudetic area) based on miospore data. Geol Quarterly 51(1):39-56

Górecka-Nowak A (2008) New interpretations of the Carboniferous stratigraphy of SW Poland based on miospore data. Bull Geosci 83(1):101-116. https://doi.org/10.3140/bull.geosci.2008.01.101

Hajná J, Žák J, Dörr W (2017) Time scales and mechanisms of growth of active margins of Gondwana: a model based on detrital zircon ages from the Neoproterozoic to Cambrian Blovice accretionary complex. Bohemian Massif Gondwana Res 42:6383. https://doi.org/10.1016/j.gr.2016.10.004

Haydukiewicz J, Muszer J, Kłapciński J (1999) Palaeontological documentation of the sub-Permian sediments in the vicinity of Zbąszyń (Fore-Sudetic Monocline) (in Polish). In: Muszer A (ed) Selected problems of stratigraphy, tectonics and ore mineralization in Lower Silesia, Wrocław

Herron MM (1988) Geochemical classification of terrigenous sands and shales from core or log data. J Sediment Petrol 58:820-829. https://doi.org/10.1306/212F8E77-2B24-11D7-8648000102 C1865D

Holub FV, Cocherie A, Rossi P (1997) Radiometric dating of granitic rocks from the Central Bohemian Plutonic Complex (Czech Republic): constraints on the chronology of thermal and tectonic events along the Moldanubian-Barrandian boundary. Comptes Rendus de 1' Academie des Sciences, Sciences de la terre et des planetes 325:19-26. https://doi.org/10.1016/S1251 -8050(97)83268-5

Jackson SE, Pearson NJ, Griffin WL, Belousova EA (2004) The application of laser ablation-inductively coupled plasma-mass spectrometry to in situ U-Pb zircon geochronology. Chem Geol 211:47-69. https://doi.org/10.1016/j.chemgeo.2004.06.017

Janoušek V, Gerdes A (2003) Timing the magmatic activity within the Central Bohemian Pluton, Czech Republic: conventional
$\mathrm{U}-\mathrm{Pb}$ ages for the Sázava and Tábor intrusions and their geotectonic significance. J Czech Geol Soc 48:70-71

Janoušek V, Holub FV (2007) The causal link between HP-HT metamorphism and ultrapotassic magmatism in collisional orogens: case study from the Moldanubian Zone of the Bohemian Massif. Proc Geol Assoc 118(1):75-86. https://doi.org/10.1016/S0016 -7878(07)80049-6

Janoušek V, Wiegand BA, Žák J (2010) Dating the onset of Variscan crustal exhumation in the core of the Bohemian Massif: new $\mathrm{U}-\mathrm{Pb}$ single zircon ages from the high-K calc-alkaline granodiorites of the Blatná suite, Central Bohemian Plutonic Complex. J Geol Soc 167:347-360. https://doi.org/10.1144/0016-76492 009-008

Jastrzębski M, Żelaźniewicz A, Murtezi M, Larionov AN, Sergeev S (2015) The Moldanubian Thrust Zone - a terrane boundary in the Central European Variscides refined based on lithostratigraphy and U-Pb zircon geochronology. Lithos 220-223(2015):116-132. https://doi.org/10.1016/j.lithos.2015.01.023

Jastrzębski M, Budzyń B, Stawikowski W (2019) Cambro-Ordovician vs Devono-Carboniferous geodynamic evolution of the Bohemian Massif: evidence from P-T-t studies in the Orlica-Śnieżnik Dome. SW Poland Geol Magazine 156(3):447-470. https://doi. org/10.1017/S0016756817000887

Karnkowski PH (2008) Tectonic subdivision of Poland: Polish Lowlands. (In Polish with English summary). Prz Geol 56:895-903

Karnkowski PH, Rdzanek K (1982) — Górny karbon (Stefan) w wierceniu Donatowo-1. Prz Geol 30(1):32-33

Košler J, Konopásek J, Sláma J, Vrána S (2013) U-Pb zircon provenance of Moldanubian metasediments in the Bohemian Massif. J Geol Soc Lond 171:83-95. https://doi.org/10.1144/jgs2013-059

Krawczyk CM, Stein E, Choi S, Oettinger G, Schuster K, Götze H-J, Haak V, Oncken O, Prodehl C, Schulze A (2000) Geophysicalconstraints on exhumation mechanisms of high-pressure rocks: the Saxo-Thuringian case between the Franconian Line and Elbe Zone, in Orogenic Processes: quantification and Modeling in the Variscan Belt, edited by W. Franke et al. Geol Soc Lond Spec Publ 179:303-322. https://doi.org/10.1144/GSL.SP.2000.179.01.18

Krawczyńska-Grocholska H (1975) Palinological studies on the Carboniferous of the north-western Poland. Prz Geol 23(1):34-35

Krawczyńska-Grocholska H (1979) Oznaczenia palinologiczno-stratygraficzne prób karbonu z wierceń NW Polski i rejonu Poznania. ZOGGN Geonafta, Warszawa

Krawczyńska-Grocholska H (1980) Palinologia karbonu NW Polski i rejonu Poznania. Uniw. Poznański. ZOGGN Geonafta, Warszawa

Krawczyńska-Grocholska H, Grocholski W (1976) Some remarks on the Carboniferous occurring on the north-western margin of the Fore-Sudetic Block. Geol Quarterly 20(1):53-64

Kroner U, Hahn T, Romer RL, Linnemann U (2007) The Variscan orogeny in the Saxo-Thuringian zone - Heterogenous overprint of Cadomian/Paleozoic Peri-Gondwana crust. In: Linnemann U, Nance RD, Kraft P, Zulauf G (eds) The evolution of the Rheic Ocean: From Avalonian-Cadomian active margin to AlleghenianVariscan collision: Geol Soc Am Spec Pap 423: 153-172. doi: 10.1130/2007.2423(06)

Kroner U, Mansy JL, Mazur S, Aleksandrowski P, Hann HP, Huckriede H, Lacquement F, Lamarche J, Ledru P, Pharao TC, Zedler H, Zeh A \& Zulauf G (2008), Variscan tectonics. In: McCann T (ed) The Geology of Central Europe, Vol. 1: Precambrian and Paleozoic Geol Soc London, pp 599-664 https://doi.org/10.1144/CEV1P.11

Krzemiński L (2005) Provenance of Carboniferous sandstones from the Variscan foreland basins in southwestern Poland and Moravia. Biul Panstw Inst Geol 417:27-108

Krzemińska E, Krzemiński L, Petecki Z, Wiszniewska J, Salwa S, Żaba J, Gaidzik K, Williams IS, Rosowiecka O, Taran L, Johansson A, Pécskay Z, Demaiffe D, Grabowski J, Zieliński G (2017) Geological map of crystalline basement in the polish part of the 
east European platform 1:1 000,000, Polish Geological Institute National Research Institute. Ministry of Environment, Warszawa

Krzywiec P, Gągała L, Mazur S et al (2017) Variscan deformation along the Teisseyre-Tornquist Zone in SE Poland: thick-skinned structural inheritance or thin-skinned thrusting? Tectonophysics 718:83-91. https://doi.org/10.1016/j.tecto.2017.06.008

Linnemann U, Romer R (2002) The Cadomian Orogeny in SaxoThuringia, Germany: geochemical and $\mathrm{Nd}-\mathrm{Sr}-\mathrm{Pb}$ isotopic characterization of marginal basins with constraints to geotectonic setting and provenance. Tectonophysics 352:33-64. https://doi. org/10.1016/S0040-1951(02)00188-9

Ludwig KR (2008) Isoplot 3.70. A geochronological toolkit for Microsoft Excel. Berkley Geochronology Center Special Publication. 4, Berkley

McCann T (2008) (ed) The geology of central Europe, Vol. 1: Precambrian and Paleozoic Geol Soc London, pp 599-664

Malinowski M, Żelaźniewicz A, Grad M, Guterch A, Janik T, CELEBRATION Working Group (2005) Seismic and geological structure of the crust in the transition from Baltica to Palaeozoic Europe in SE Poland-CELEBRATION 2000 experiment, profile CEL02. Tectonophysics 401(1-2):55-77. https://doi. org/10.1016/j.tecto.2005.03.011

Matte P (2001) The Variscan collage and orogeny (480-290 $\mathrm{Ma})$ and the tectonic definition of the Armorica microplate: a review. Terra Nova 13:122-128. https://doi.org/10.104 6/j.1365-3121.2001.00327.x

Mazur S, Kurowski L, Aleksandrowski P, Żelaźniewicz A (2003) Variscan foreland fold-thrust belt of Wielkopolska (W Poland): new structural and sedimentological data. Geolines 16:71

Mazur S, Aleksandrowski P, Kryza R, Oberc-Dziedzic T (2006a) The Variscan Orogen in Poland. Geol Quarterly 50(1):89-118

Mazur S, Dunlap WJ, Turniak K, Oberc-Dziedzic T (2006b) Age constraints for the thermal evolution and erosional history of the central European Variscan belt: new data from the sediments and basement of the Carboniferous foreland basin in western Poland. J Geol Soc London 163(6):1011-1024. https://doi. org/10.1144/0016-76492004-170

Mazur S, Aleksandrowski P, Szczepański J (2010a) Outline structure and tectonic evolution of the Variscan Sudetes. Prz Geol 58:133-145

Mazur S, Aleksandrowski P, Turniak K, Krzemiński L, Mastalerz K, Górecka-Nowak A, Kurowski L, Krzywiec P, Żelaźniewicz A, Fanning MC (2010b) Uplift and late orogenic deformation of the Central European Variscan belt as revealed by sediment provenance and structural record in the Carboniferous foreland basin of western Poland. Int J Earth Sci 99:47-64. https://doi.org/10.1007/ s00531-008-0367-3

Mazur S, Mikołajczak M, Krzywiec P, Malinowski M, Buffenmyer V, Lewandowski M (2015a) Is the Teisseyre-Tornquist Zone an ancient plate boundary of Baltica? Tectonics 34:2465-2477. https ://doi.org/10.1002/2015TC003934

Mazur S, Turniak K, Szczepański J, McNaughton NJ (2015b) Vestiges of Saxothuringian crust in the Central Sudetes, Bohemian Massif: zircon evidence of a recycled subducted slab provenance. Gondwana Res 27(2):825-839. https://doi.org/10.1016/j.gr.2013.11.005

Mazur S, Krzywiec P, Malinowski M, Lewandowski M, Aleksandrowski P, Mikołajczak M (2018) On the nature of the TeisseyreTornquist Zone. Geol Geophys Environ 44:17-30. https://doi. org/10.7494/geol.2018.44.1.17

Mikulski SZ, Williams IS, Bagiński B (2013) Early Carboniferous (Visean) emplacement of the collisional Kłodzko-Złoty Stok granitoids (Sudetes, SW Poland): constraints from geochemical data and zircon U-Pb ages. Int J Earth Sci 102:1007-1027. https ://doi.org/10.1007/s00531-012-0852-6
Oberc J (1987) Rola bloków litosfery i ruchy przesuwcze w przedmolasowym rozwoju waryscydów na brzegach masywu czeskiego. Prz Geol 35(6):290-299

Oplustil S, Schmitz M, Cleal CJ, Martınek K (2016) A review of the Middle-Late Pennsylvanian west European regional substages and floral biozones, and their correlation to the Geological Time Scale based on new U-Pb ages. Earth-Sci Rev 154:301-335. https://doi. org/10.1016/j.earscirev.2016.01.004

Owens B, Lean MCD, Bodman D (2004) A revised palynozonation of British Namurian deposits and comparisons with eastern Europe. Micropaleontology 50:89-103. https://doi.org/10.2113/50.1.89

Paton C, Woodhead JD, Hellstrom JC, Hergt JM, Greig A, Maas R (2010) Improved laser ablation U-Pb zircon geochronology through robust downhole fractionation correction. Geochem Geophy Geosy. https://doi.org/10.1029/2009GC002618

Pertoldová J, Verner K, Vrána S, Buriánek D, Štědrá V, Vondrovic L (2010) Comparison of lithology and tectonometamorphic evolution of units at the northern margin of the Moldanubian Zone: implications for geodynamic evolution in the northeastern part of the Bohemian Massif. J Geosci 55:299-319. https://doi. org/10.3190/jgeosci.083

Petrus JA, Kamber BS (2012) VizualAge: a novel approach to laser ablation ICP-MS U-Pb geochronology data reduction. Geostand Geoanal Res 36:247-270. https://doi.org/10.1111/j.1751908X.2012.00158.x

Pietranik A, Storey C, Kierczak J (2013) The Niemcza diorites and monzodiorites (Sudetes, SW Poland): a record of changing geotectonic setting at ca. $340 \mathrm{Ma}$. Geol Quarterly 57:325-334

Ricken W, Schrader S, Oncken O, Plesch A (2000) Turbidite basin and mass dynamics related to orogenic wedge growth; the RhenoHercynian case. Geol Soc Spec Pub 179:257-280. https://doi. org/10.1144/GSL.SP.2000.179.01.16

Schaltegger U, Schmitt AK, Horstwood MS (2015) U-Th-Pb zircon geochronology by ID-TIMS, SIMS, and laser ablation ICP-MS: recipes, interpretations and opportunities. Chem Geol 402:89110. https://doi.org/10.1016/j.chemgeo.2015.02.028

Schulmann K, Kröner A, Hegner E, Wendt I, Konopásek J, Lexa O, Štípská P (2005) Chronological constraints on the pre-orogenic history, burial and exhumation of deep-seated rocks along the eastern margin of the Variscan orogen, Bohemian Massif, Czech Republic. Am J Sci 305:407-448. https://doi.org/10.2475/ ajs.305.5.407

Siebel W, Blaha U, Chen F, Rohrmüller J (2005) Geochronology and geochemistry of a dyke-host rock association and implications for the formation of the Bavarian Pfahl shear zone, Bohemian Massif. Int J Earth Sci 94:8-23. https://doi.org/10.1007/s0053 1-004-0445-0

Sláma J, Košler J, Condon DJ, Crowley JL, Gerdes A, Hanchar JM, Horstwood MSA, Morris GA, Nasdala L, Norberg N, Schaltegger U, Schoene B, Tubrett MN, Whitehouse MJ (2008) Plesovice zircon - a new natural reference material for $\mathrm{U}-\mathrm{Pb}$ and $\mathrm{Hf}$ isotopic microanalysis. Chem Geol 249:1-35. https://doi.org/10.1016/j. chemgeo.2007.11.005

Spencer CJ, Kirkland CL, Taylor RJM (2016) Strategies towards statistically robust interpretations of in situ U-Pb zircon geochronology. Geosci Front 7(4):581-589. https://doi.org/10.1016/j. gsf.2015.11.006

Środoń J, Drits VA, McCarty DK, Hsieh JC, Eberl DD (2001) Quantitative X-ray diffraction analysis of clay-bearing rocks from random preparations Clay. Clay Miner 49:514-528. https://doi. org/10.1346/CCMN.2001.0490604

Tait J, Schätz M, Bachtadse V, Soffel H (2000) Palaeomagnetism and Palaeozoic palaeogeography of Gondwana and European terranes. Geol Soc Spec Publ 179:21-34. https://doi.org/10.1144/ GSL.SP.2000.179.01.04 
Taylor SR, McLennan SM (1985) The continental crust: its composition and evolution. Blackwell, Oxford. https://doi.org/10.1002/ gj.3350210116

Tunheng A, Hirata T (2004) Development of signal smoothing device for precise elemental analysis using laser ablation-ICP-mass spectrometry. J Anal Atom Spectrom 19:932. https://doi.org/10.1039/ b402493a

Wierzchowska-Kicułowa K (1984) Budowa geologiczna utworów podpermskich monokliny przedsudeckiej. Geol Sudetica 19:121-142

Wetherill GW (1956) An interpretation of the Rhodesia and Witwatersrand age patterns. Geochim Cosmochim Acta 9(5):290-292. https://doi.org/10.1016/0016-7037(56)90029-1

Wiedenbeck M, Alle P, Corfu F, Griffin WL, Meier M, Oberli F, Vonquadt A, Roddick JC, Speigel W (1995) 3 natural zircon standards for U-Th-Pb, Lu-Hf, trace-element and REE analyses. Geostandards Newslett 19:1-23. https://doi.org/10.1111/j.1751-908X.1995. tb00147.x

Winchester JA, Network PACETMR (2002) Palaeozoic amalgamation of Central Europe: new results from recent geological and geophysical investigations. Tectonophysics 360:5-22. https://doi. org/10.1016/S0040-1951(02)00344-X

Żelaźniewicz A, Marheine D, Oberc-Dziedzic T (2003) A Late Tournaisian synmetamorphic folding and thrusting event in the eastern Variscan foreland: 40Ar/39Ar evidence from the phyllites of the Wolsztyn-Leszno High, western Poland. Int J Earth Sci 92:185194. https://doi.org/10.1007/s00531-002-0306-7

Żelaźniewicz A, Aleksandrowski P, Buła Z, Konon A, Oszczypko N, Ślączka A, Żaba J, Żytko K (2011) Regionalizacja tektoniczna Polski. Komitet Nauk Geologicznych PAN Wrocław ISBN 978-83-63377-01-4
Żelaźniewicz A, Buła Z, Jachowicz M, Żaba J (1997) The crystalline basement SW of the Trans-European Suture Zone in Poland: Neoproterozoic (Cadomian) orogen. Terra Nostra 11:167-171

Żelaźniewicz A, Buła Z, Fanning M, Seghedi A, Żaba J (2009) More evidence on Neoproterozoic terranes in southern Poland and southeastern Romania. Geol Quarterly 53:93-124

Żelaźniewicz A, Oberc-Dziedzic T, Fanning CM, Protas A, Muszyński A (2016) Late Carboniferous-early Permian events in the TransEuropean Suture Zone: tectonic and acid magmatic evidence from Poland. Tectonophysics 675:227-243. https://doi.org/10.1016/j. tecto.2016.02.040

Żelaźniewicz A, Oberc-Dziedzic T, Sláma J (2020) Baltica and the Cadomian orogen in the Ediacaran-Cambrian: a perspective from SE Poland. Int J Earth Sci (Geol Rundsch). https://doi. org/10.1007/s00531-020-01858-0

Žák J, Holub F, Verner K (2005) Tectonic evolution of a continental magmatic arc from transpression in the upper crust to exhumation of mid-crustal orogenic root recorded by episodically emplaced plutons: the Central Bohemian Plutonic Complex (Bohemian Massif). Int J Earth Sci 94:385-400. https://doi.org/10.1007/ s00531-005-0482-3

Žák J, Verner K, Janoušek V, Holub FV, Kachlík V, Finger F, Hajná J, Tomek F, Vondrovic L, Trubač J (2014) A plate-kinematic model for the assembly of the Bohemian Massif constrained by structural relationships around granitoid plutons. In: Schulmann K, Oggiano G, Lardeaux JM, Janoušek V, Martínez Catalán JR (eds) The Variscan orogeny: extent, timescale and the formation of the European crust, vol 405. Geological Society, Special Publications, London, pp 169-196. https://doi.org/10.1144/SP405.9 